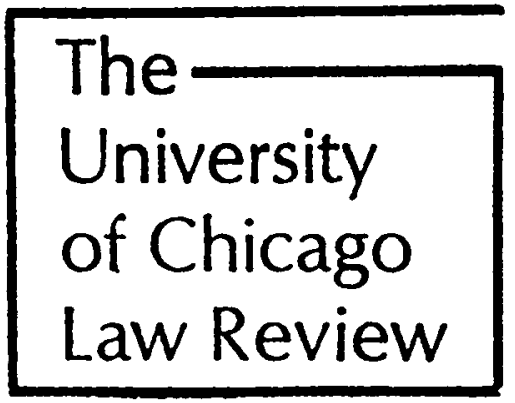

VOLUME 49 NUMBER 1 WINTER 1982

- 1982 by The University of Chicago

\title{
Problems in Assessing Punitive Damages Against Manufacturers of Defective Products
}

\author{
David G. Owen $\dagger$
}

In early February 1978, the legal and business communities were stunned when a Santa Ana, California, jury returned a verdict for $\$ 125$ million in punitive damages in the case of Grimshaw $v$. Ford Motor Co. ${ }^{1}$ The case involved the design of the first modern American subcompact car, the Ford Pinto, ${ }^{2}$ and arose from the

$\dagger$ Professor of Law, University of South Carolina. I am indebted to a number of persons who made helpful suggestions on earlier drafts of this paper, especially Lawrence $H$. Curtis, John P. Eppel, Richard A. Epstein, William D. Ford, Gary J. Haugen, James A. Henderson, Jr., Frances S. Owen, Jerry J. Phillips, Hon. Richard A. Posner, Victor E. Schwartz, Aaron D. Twerski, John W. Wade, and Malcolm E. Wheeler.

1 No. 19-77-61 (Super. Ct., Orange Cty., Cal., Feb. 7, 1978), aff'd as amended, 119 Cal. App. 3d 757, 174 Cal. Rptr. 348 (1981).

2 General discussions of the issues in the Pinto civil litigation include Bruck, How Ford Stalled the Pinto Litigation, Am. Law., June 1979, at 23; Dowie, Pinto Madness, MormrR Jonss, Sept./Oct. 1977, at 18; Owen, Crashworthiness Litigation and Punitive Damages, 4 J. Prods. Liab. 221 (1981); Schmitt \& May, Beyond Products Liability: The Legal, Social, and Ethical Problems Facing the Automobile Industry in Producing Safe Products, $56 \mathrm{U}$. DET. J. URB. L. 1021 (1979).

For discussions of the criminal litigation involving the Pinto, see L. STOBEL, ReckLess Homicide? (1980); Epstein, Is Pinto a Criminal?, Reg., Mar./Apr. 1980, at 15; Tybor, How Ford Won Pinto Trial, Nat'l L.J., Mar. 24, 1980, at 1. See also the series of National Law Journal articles by Professor Malcolm E. Wheeler on the prospect and implications of future criminal trials in the products liability context: In Pinto's Wake, Criminal Trials Loom for More Manufacturers, Nat'l L.J., Oct. 6, 1980, at 27; The Public's Costly Mistrust of 
death of a driver and severe burns suffered by a young passenger, Richard Grimshaw, in a Pinto that burst into flames when its gas tank ruptured upon being struck from the rear by another vehicle. ${ }^{3}$ The enormous verdict for punitive damages was based on jury findings that Ford knew of dangers in the fuel system before the car was placed on the market and, although the company also knew that it could remedy the problem through inexpensive design changes, chose instead to sell the car in its dangerous condition to save on costs. ${ }^{4}$ The trial court subsequently remitted the punitive damages verdict to $\$ 3.5$ million. ${ }^{5}$ The California Court of Appeal recently affirmed the verdict as remitted in a lengthy opinion that characterized Ford's conduct in marketing the Pinto as "reprehensible in the extreme."

In 1976 I published in the Michigan Law Review the results of my study on the use of punitive damages in products liability litigation. ${ }^{7}$ Although a number of juries already had rendered such awards, ${ }^{8}$ there was at that time very scant appellate authority for punitive awards in this context. ${ }^{2}$ The largest such judgment ap-

Cost-Benefit Safety Analysis, id., Oct. 13, 1980, at 26 [hereinafter cited as Costly Mistrust]; Cost-Benefit Analysis on Trial: A Case of Delusion and Reality, id., Oct. 20, 1980, at 28; Manufacturers: Wrong Targets for Threat of Criminal Sanctions?, id., Dec. 22, 1980, at 24; Enforcing Product Safety: A Maze of Legal Issues and Ramifications, id., Dec. 29, 1980, at 23.

s Grimshaw v. Ford Motor Co., 119 Cal. App. 3d 757, 773-74, 174 Cal. Rptr. 348, 359 (1981).

Id. at 774-78, 174 Cal. Rptr. at 359-62. The danger alleged in the fuel system's design was its particular vulnerability to rupture when hit from the rear at relatively low speeds, with the resulting risk of fire if escaping fuel ignited. Specific claims of design inadequacy that allegedly aggravated the situation included the location of the fuel tank within only nine or ten inches (of "crush space") from the rear bumper, the flimsiness of the bumper itself, the absence of reinforcing members in the rear frame, and the positioning of the fuel tank just behind the differential housing with sharp protrusions pointing directly at the tank. Id. at 774, $174 \mathrm{Cal}$. Rptr. at 360 . In addition, read in the light most favorable to the plaintiffs, the evidence showed that there were a variety of corrective design changes (socalled safety "fixes") that were feasible and economical. See id. at 775-76, 174 Cal. Rptr. at 361; note 149 infra.

s Grimshaw v. Ford Motor Co., No. 19-77-61 (Super. Ct., Orange Cty., Cal., Mar. 30, 1978) (mem. order), aff'd, 119 Cal. App. 3d 757, 174 Cal. Rptr. 348 (1981). Grimshaw was required to accept the remittitur as a condition of the trial court's denial of Ford's motion for a new trial. Id. at 4-5.

- Grimshaw v. Ford Motor Co., 119 Cal. App. 3d 757, 819, 174 Cal. Rptr. 348, 388 (1981) (viewing the evidence in the light most favorable to the judgment).

' Owen, Punitive Damages in Products Liability Litigation, 74 MrcH. L. Rev. 1257 (1976).

${ }^{8}$ See id. at 1328 n.334.

- Jury awards had been reinstated or upheld on appeal in only three cases: Gillham v. Admiral Corp., 523 F.2d 102 (6th Cir. 1975) (\$100,000), cert. denied, 424 U.S. 913 (1976); 
proved by an appellate court at the time was for $\$ 250,000$ in California for the fraudulent marketing of a dangerous drug. ${ }^{10}$ Signs that the judicial environment was changing were apparent, ${ }^{11}$ and I concluded then that "[ $t]$ he assimilation of the punitive damages remedy into the field of products liability has just begun."12 The recent affirmance of the verdict in Grimshaw demonstrates that the assimilation is now in full swing.

There has been considerable ferment in this field in the last few years. The Court of Appeals for the Fifth Circuit recently reinstated a $\$ 5$ million punitive damages award in a crashworthiness case for injuries to the driver of a "diminutive" Honda automobile. ${ }^{13}$ Two state supreme courts have also upheld million dollar punitive awards in products liability cases. In Gryc v. DaytonHudson Corp. ${ }^{14}$ the Minnesota Supreme Court approved such an award in a case against Riegel Textile Corporation for its failure to add flame retardants to the cotton flannelette it sold for use in nightgowns for young girls. More recently, the Ohio Supreme Court affirmed such an award in an action against American Motors for failing properly to crash-test one model of its Jeep for the durability of its roll-bar in forward pitchovers. ${ }^{15}$

In addition, there have been of late several multi-million dollar punitive damages awards at the trial level in products liability cases, ${ }^{16}$ and several important judicial opinions have been writ-

Toole v. Richardson-Merrell Inc., 251 Cal. App. 2d 689, 60 Cal. Rptr. 398 (1967) (\$250,000, as remitted by trial court); Moore v. Jewel Tea Co., 116 Ill. App. 2d 109, 253 N.E.2d 636 (1969), aff'd, 46 III. 2d 288, 263 N.E.2d 103 (1970) $(\$ 10,000)$.

10 Toole v. Richardson-Merrell Inc., 251 Cal. App. 2d 689, 60 Cal. Rptr. 398 (1967). The case involved the sale of MER/29, an anticholesterol drug. See generally Owen, supra note 7 , at 1329-32. The plaintiff had accepted a remission to $\$ 250,000$ of the jury's $\$ 500,000$ award as a condition of the trial court's denial of the defendant's motion for a new trial. 251 Cal. App. 2d at 693-94, 60 Cal. Rptr. at 403.

11 See Owen, supra note 7 , at 1261 .

12 Id. at 1371.

18 Dorsey v. Honda Motor Co., 655 F.2d 650 (5th Cir. 1981).

14297 N.W.2d 727 (Minn.), cert. denied, 449 U.S. 921 (1980).

${ }^{18}$ Leichtamer v. American Motors Corp., 67 Ohio St. 2d 456, 424 N.E.2d 568 (1981).

16 See, e.g., Chastain v. Lynndale Int'l, Inc., No. CIV-80-23 (Cir. Ct., Cleburne Cty., Ark., Sept. 4, 1981) (\$3 million punitive damages jury verdict); Palmer v. A.H. Robins Co., No. C60442 (Dist. Ct., Denver Cty., Colo., filed July 30, 1979) (\$6.2 million punitive damages jury verdict); Moll v. Toyota Motor Co., No. 79-17458 (Cir. Ct., Broward Cty., Fla., Sept. 8, 1981) ( $\$ 3$ million punitive damages jury verdict); Wolmer v. Chrysler Corp., No. 78-1130 (Cir. Ct., Broward Cty., Fla., Aug. 28, 1981) (\$3 million punitive damages jury verdict); Stambaugh v. International Harvester Co., No. 78-L-2775 (Cir. Ct., St. Clair Cty., Ill., Oct. 26,1979 ) ( $\$ 15$ million punitive damages jury verdict; remitted by trial judge to $\$ 7.5$ million, Mar. 10, 1980); Ford Motor Co. v. Nowak, No. 23,608 (Dist. Ct., Matagorda Cty., Tex., May 
ten on the issue. ${ }^{17}$ In one such case, Maxey v. Freightliner Corp. ${ }^{18}$ the jury returned a $\$ 10$ million punitive damages verdict for the design of the fuel system of a truck tractor that tipped over and caught fire. Issuing a detailed opinion explaining his rationale, the federal trial judge granted in part the defendant's motion for judgment notwithstanding the verdict and set aside the jury's verdict for punitive damages. ${ }^{18}$ The court's judgment was affirmed by a split panel of the Court of Appeals for the Fifth Circuit, ${ }^{20}$ and the full court has agreed to rehear the case en banc. ${ }^{21}$ In Palmer $v$. A.H. Robins Co., ${ }^{22}$ involving complications from the design of the Dalkon Shield, an intrauterine device, a Colorado jury returned a punitive damages verdict of $\$ 6.2$ million; that case is presently on appeal. In Sturm, Ruger \& Co. v. Day, ${ }^{28}$ the jury awarded $\$ 2.9$ million in punitive damages for design and warnings inadequacies in a revolver to a man who was shot in the leg when he dropped the gun. On appeal, the Alaska Supreme Court held that the evidence would support a punitive award of only $\$ 250,000$ and remanded for a new trial; ${ }^{24}$ on rehearing, the court mysteriously approved immediate entry of a remitted punitive damages judgment of $\$ 500,000 .^{25}$

Other important cases presently on appeal include a judgment against Ford, involving the slippage of a transmission from the park position to reverse, in which a Texas jury awarded $\$ 4$ million in punitive damages, ${ }^{26}$ and a $\$ 15$ million verdict in Illinois, remitted by the trial judge to $\$ 7.5$ million, involving the design of an

29,1980 ) ( $\$ 4$ million punitive damages jury verdict).

${ }^{17}$ The significant judicial opinions written in this area since 1976 include Drayton v. Jiffee Chem. Corp., 591 F.2d 352 (6th Cir. 1978), modifying and aff'g 395 F. Supp. 1081 (N.D. Ohio 1975); Maxey v. Freightliner Corp., 450 F. Supp. 955 (N.D. Tex. 1978), aff'd, 623 F.2d 395 (5th Cir.), rehearing en banc granted, 634 F.2d 1008 (5th Cir. 1980); Sturm, Ruger \& Co. v. Day, 594 P.2d 38 (Alaska 1979), on rehearing, 615 P.2d 621 (1980); Grimshaw v. Ford Motor Co., 119 Cal. App. 3d 757, 174 Cal. Rptr. 348 (1981); Moore v. Remington Arms Co., 100 Ill. App. 3d 1102, 427 N.E.2d 608 (1981); American Laundry Mach. Indus. v. Horan, 45 Md. App. 97, 412 A.2d 407 (1980); Gryc v. Dayton-Hudson Corp., 297 N.W.2d 727 (Minn.), cert. denied, 449 U.S. 921 (1980); Rinker v. Ford Motor Co., 567 S.W.2d 655 (Mo. Ct. App. 1978); Wangen v. Ford Motor Co., 97 Wis. 2d 260, 294 N.W.2d 437 (1980).

${ }_{18} 450$ F. Supp. 955 (N.D. Tex. 1978), aff'd, 623 F.2d 395 (5th Cir.), rehearing en banc granted, 634 F.2d 1008 (5th Cir. 1980).

${ }^{10} \mathrm{Id}$. at $961-66$. The court allowed the verdict for $\$ 150,000$ actual damages to stand.

${ }^{20} 623$ F.2d 395 (5th Cir. 1980) (2-1 decision).

21634 F.2d 1008 (5th Cir. 1980).

${ }_{22}$ No. C60442 (Dist. Ct., Denver Cty., Colo., filed July 30, 1979).

29594 P.2d 38 (Alaska 1979), on rehearing, 615 P.2d 621 (1980).

24 Id. at $48-49$.

${ }^{25} 615$ P.2d 621, 624 (Alaska 1980).

${ }^{26}$ Ford Motor Co. v. Nowak, No. 23608 (Dist. Ct., Matagorda Cty., Tex., May 29, 1980). 
International Harvester tractor's gasoline fuel system. ${ }^{27}$ A number of other appellate decisions in recent years have examined in differing contexts punitive damages awards in products liability cases. $^{28}$

${ }^{27}$ Stambaugh v. International Harvester Co., No. 76-L-2775 (Cir. Ct., St. Clair Cty., Ill., Oct. 26, 1979).

${ }^{28}$ See, e.g., Kicklighter v. Nails by Jannee, Inc., 616 F.2d 734, 738 (5th Cir. 1980) (affirming trial court's judgment notwithstanding the verdict setting aside $\$ 60,000$ punitive damages award against manufacturer of artificial fingernail kit containing chemicals whose fumes made plaintiff ill); McIntyre v. Everest \& Jennings, Inc., 575 F.2d 155, 160 (8th Cir.) (affirming trial court's vacation of a $\$ 45,000$ punitive damages award in suit for injuries suffered in fall from commode chair manufactured by defendant), cert. denied, 439 U.S. 864 (1978); d'Hedouville v. Pioneer Hotel Co., 552 F.2d 886, 894 \& n.18 (9th Cir. 1977) (approving submission to jury of punitive damages claim in suit against manufacturer of flammable fiber used in hotel carpeting that caught fire, killing plaintiff's decedent; no punitive award by jury); Knippen v. Ford Motor Co., 546 F.2d 993, 1002-03 (D.C. Cir. 1976) (affirming directed verdict for defendant manufacturer on punitive damages claim by motorcyclist injured in collision with station wagon manufactured by defendant); In re Northern Dist. "Dalkon Shield" IUD Prods. Liab. Litig., 521 F. Supp. 1188, 1191 (N.D. Cal. 1981) (conditional certification of national class action on punitive damages claims), full op. issued, No. 80-2213 (Nov. 5, 1981); Forrest City Mach. Works, Inc. v. Aderhold, 616 S.W.2d 720, 726 (Ark. 1981) (reversing punitive damages award of $\$ 500,000$ against manufacturer of grain.cart in which a child caught his leg); American Motors Corp. v. Ellis, 403 So. 2d 459, 467-68 (Fla. Dist. Ct. App. 1981) (reversing directed verdict for defendant car manufacturer on punitive damages claim); Ellis v. Golconda Corp., 352 So. 2d 1221, 1225 (Fla. Dist. Ct. App. 1977) (holding that evidence did not support a $\$ 70,000$ punitive damages award in suits against owner of tank truck and others arising from explosion of liquid petroleum that escaped from truck), cert. denied, 365 So. 2d 714 (Fla. 1978); Auto Specialties Mfg. Co. v. Boutwell, 335 So. 2d 291, 292 (Fla. Dist. Ct. App.) (affirming directed verdict denying punitive damages to a plaintiff injured when hydraulic jack manufactured by defendant exploded), cert. dismissed, 341 So. 2d 1080 (Fla. 1976), disapproved on other grounds, Goodyear Tire \& Rubber Co. v. Hughes Supply, Inc., 358 So. 2d 1339, 1343 (Fla. 1978); Beerman v. Toro Mfg. Corp., 615 P.2d 749, 755 (Hawaii Ct. App. 1980) (holding that satisfaction of compensatory judgment against defendant city would not bar recovery of punitive damages against distributor and manufacturer of city-operated power mower that threw object into plaintiff's eye; claims against distributor and manufacturer had been dismissed by trial court); Turney v. Ford Motor Co., $94 \mathrm{Il}$. App. 3d 678, 685-86, 418 N.E.2d 1079, 1085-86 (1981) (affirming dismissal of punitive damages claim against manufacturer of tractor from which plaintiff operator was thrown); Conder v. Hull Lift Truck, Inc., 405 N.E.2d 538, 547 (Ind. Ct. App. 1980) (upholding trial court's refusal of plaintiff's instruction on "willful and wanton misconduct"; jury verdict for defendant manufacturer of forklift truck that rolled over, severely injuring plaintiff); Cantrell v. Amarillo Hardware Co., 226 Kan. 681, 686-87, 602 P.2d 1326, 1331 (1979) (affirming $\$ 18,500$ punitive damages award against manufacturer of aluminum stepladder that collapsed, injuring plaintiff); Harley-Davidson Motor Co. v. Wisniewski, 437 A.2d 700, 705 (Md. Ct. Spec. App. 1981) (vacating $\$ 1.9$ million punitive damages award for defective assembly of motorcycle throttle); Racer v. Utterman, 1981 Prod. Liab. ReP. (CCH) \& 9082 (Mo. Ct. App. Sept. 22, 1981) (reversing $\$ 500,000$ punitive damages award against manufacturer of flammable surgical drape for failure to instruct on issues of manufacturer's fault and knowledge of danger); Rawlings Sporting Goods Co. v. Daniels, 619 S.W.2d 435, $439-41$ (Tex. Civ. App. 1981) (affirming \$750,000 punitive damages award to high school football player against manufacturer of helmet for failure to warn 
When I studied this issue last, I concluded that such damages are appropriate on those infrequent occasions when a manufacturer is proven to have been flagrantly at fault in selling a defective product. My purpose then was to demonstrate the validity in principle of allowing punitive damages awards in appropriate products liability cases, and I offered guidelines for helping to determine their proper application. ${ }^{29}$ Such awards have become well accepted in principle, and my concern is now that large awards of this type are becoming almost common..$^{30} \mathrm{I}$ have noted recently the importance of thinking through the fundamental values underlying the range of choices that face the courts in products liability cases in the years ahead. ${ }^{31}$ Large assessments of punitive damages may not yet be a major threat to the continued viability of most manufacturing concerns, but the increasing number and size of such awards may fairly raise concern for the future stability of American industry. ${ }^{32}$

against risk of subdural hematoma brain injury); Newding v. Kroger Co., 554 S.W.2d 15, 18 (Tex. Civ. App. 1977) (affirming judgment notwithstanding the verdict setting aside $\$ 60,000$ punitive damages awards in suit against beverage distributor and bottling company by plaintiff whose eye was struck by ejected twist-off cap); Wangen v. Ford Motor Co., 97 Wis. $2 \mathrm{~d} 260,294$ N.W.2d 437 (1980) (interlocutory appeal) (approving award of punitive damages in products liability suits); Wussow v. Commercial Mechanisms, Inc., 97 Wis. 2d 136, 152-56, 293 N.W.2d 897, 905-08 (1980) (affirming jury awards of $\$ 70,000$ in punitive damages against manufacturer of baseball pitching machine, the arm of which struck plaintiff). See also United School Dist. No. 490 v. Celotex Corp., 629 P.2d 196, 211 (Kan. Ct. App. 1981) (affirming $\$ 600,000$ punitive damages award for fraud by manufacturer of roofing system); Kirschnik v. Pepsi-Cola Metropolitan Bottling Co., 478 F. Supp. 842, 844-45 (E.D. Wis. 1979) (holding that Wisconsin law did not allow punitive damages in products liability actions based on negligence or strict liability). infra.

29 See Owen, supra note 7, at 1319, 1361-71. The factors are restated in notes 120, 242

so See Moore v. Remington Arms Co., 100 Ill. App. 3d 1102, 1114, 427 N.E.2d 608, 61617 (1981) ("The tide has . . . turned: judgments for punitive damages are now routinely entered across the nation, and staggering sums have been awarded.").

s1 See Owen, Rethinking the Policies of Strict Products Liability, 33 VAND. L. REv. 681 (1980); Product Liability: Hearings on H.R. 5571 et al. Before the Subcomm. on Consumer Protection and Finance of the House Comm. on Interstate and Foreign Commerce, 96th Cong., 1st Sess. 470-75, 476-91 (statements of David G. Owen).

s2 See Wangen v. Ford Motor Co., 97 Wis. 2d 260, 331, 294 N.W.2d 437, 472 (1980) (Coffey, J., dissenting) ("The implications for the free enterprise system, and therefore the structure of our economy, are too disturbing to leave a decision of this magnitude to five jurists."). See also Bus. WK., Jan. 12, 1981, at 86, for observations of products liability lawyers on the increasing frequency of cases of this type; H. Nolte (Vice President \& Gen. Counsel, Ford Motor Co.), Comments on Products Liability Law 20-23 (unpublished address to ABA Comm. on Corporate Law Departments, Spring 1981) (on file with The University of Chicago Law Review). See generally U.S. Dep'T of Commerce, InTERAGEncy TAsK Force on Product Liability, Finar REPoRT VII-75 to -80 (1977) [hereinafter cited as TAsK Force Final Report] (on file with The University of Chicago Law Review). 
The time is ripe, then, to take a close look at the other side of the punitive damages question. ${ }^{33} \mathrm{My}$ purpose in this article is to examine the problems and limitations endemic to such awards in products liability litigation, to formulate afresh the appropriate standards for punitive damages liability in this context, and to focus briefly on the controls available to prevent abuse. Many of the issues examined apply in contexts other than products liability actions against manufacturing companies, particularly where other institutional defendants are involved. ${ }^{34}$

\section{Punitive Damages: General Principles}

The traditional principles of punitive damages law should be reviewed before the special problems faced by manufacturers defending punitive damages claims in products liability cases can be understood. Punitive (or "exemplary") damages are assessed in addition to compensatory damages to punish a defendant who com-

ss For recent commentary on punitive damages in products liability cases, see J. BRAsley, Products Liability and the Unreasonably Dangerous Requirement $651-70$ (1981); $R$. Epstein, Módern Products Liability Law 176-90 (1980); 3 L. Frumbr \& M. Friedman, Products Liability § 36A (1980 \& Supp. 1981); G. Ghiardi \& J. Kircher, Punitive Damages-Law and Practice \$\$ 6.01-.38 (1981); K. Redden, Punitive Damages $\$ 4.2(A)(2)$ (1980); DuBois, Punitive Damages in Personal Injury, Products Liability and Professional Malpractice Cases: Bonanza or Disaster, 43 Ins. Couns. J. 344 (1976); Fulton, Punitive Damages in Product Liability Cases, 15 Forum 117 (1979); Hoenig, Products Liability and Punitive Damages, 1980 Ins. L.J. 198; Igoe, Punitive Damages: An Analytical Perspective, Trial, Nov. 1978, at 48; Mallor \& Roberts, Punitive Damages: Toward a Principled Approach, 31 Hastings L.J. 639 (1980); Owen, supra note 2; Schmitt \& May, supra note 2; Note, Mass Liability and Punitive Damages Overkill, 30 Hastings L.J. 1797 (1979); Comment, Punitive Damages in Products Liability, 16 Santa ClarA L. Rev. 895 (1976). See also Note, In Defense of Punitive Damages, 55 N.Y.U. L. REv. 303 (1980) [hereinafter cited as N.Y.U. Note]. Other articles in this area are cited in Owen, supra note 7, at 1260 n.9.

s4 A variety of significant punitive damages assessments has been levied against nonmanufacturing institutional defendants in recent years. See, e.g., Silkwood v. Kerr-McGee Corp., 485 F. Supp. 566 (W.D. Okla. 1979) ( $\$ 10$ million punitive damages verdict and judgment for radiation injury to worker in nuclear fuel-processing plant where defendant operator allegedly allowed plutonium to escape), rev'd in part, No. 79-1894 (10th Cir. Dec. 11, 1981) (2-1 decision) (punitive damages under state law preempted by Price-Anderson Act); Egan v. Mutual of Omaha Ins. Co., 24 Cal. 3d 809, 598 P.2d 452, 157 Cal. Rptr. 482 (1979) ( $\$ 5$ million punitive damages verdict, for bad faith failure to investigate properly insured's disability insurance claim, reversed for excessiveness), appeal dismissed, 445 U.S. 912 (1980); Rosener v. Sears Roebuck \& Co., 110 Cal. App. 3d 740, 168 Cal. Rptr. 237 (1980) (\$10 million verdict and judgment for punitive damages for fraudulent home improvement program vacated unless plaintiff accepted remission to $\$ 2.5$ million), appeal dismissed, 450 U.S. 1051 (1981); Hall v. Consolidated Edison Corp., 104 Misc. 2d 565, 428 N.Y.S.2d 837 (Sup. Ct. 1980) (tenant slipped on wax drippings in darkened hallway of apartment dwelling where defendant utility had cut off electricity for landlord's nonpayment of bill; $\$ 5$ million punitive damages verdict reversed unless plaintiff accepted remission to $\$ 50,000$ ). 
mits an aggravated or outrageous act of misconduct against the plaintiff and to deter the defendant and others from similar misbehavior in the future. ${ }^{35}$ Punitive damages are considered quasi-criminal, a remedy standing halfway between the civil and the criminal law: the purpose of such damages is punishment and deterrence rather than compensation, yet the punitive assessment is awarded to the plaintiff in a private lawsuit. ${ }^{36}$ For procedural purposes, however, punitive damages are treated as civil law damages, so that criminal law safeguards (such as the prohibitions against double jeopardy, excessive fines, and compulsory self-incrimination) generally have not been applied. ${ }^{37}$

All states except four ${ }^{38}$ appear to have doctrines allowing for punitive damages in some form, although in a few states such awards are viewed as a form of additional compensation and thus are somewhat limited in amount. ${ }^{39}$ Punitive damages are not available in most states for breach of contract; ${ }^{40}$ some states prohibit their award in wrongful death actions; ${ }^{41}$ and some place a variety

ss See Restatement (Second) of Torts § 908(1) \& comment a (1979) [hereinafter cited as RESTATEMENT].

so See id. \& 908 comment a (purposes of punitive damages and criminal fines are the same).

${ }^{37}$ See generally Comment, Criminal Safeguards and the Punitive Damages Defendant, 34 U. CHI. L. Rev. 408 (1967).

ss These four are Louisiana, see, e.g., Ricard v. State, 390 So. 2d 882, 884 (La. 1980); Massachusetts, see, e.g., Caperci v. Huntoon, 397 F.2d 799, 801 (1st Cir.) (dictum), cert. denied, 393 U.S. 940 (1968); Nebraska, see, e.g., Prather v. Eisenmann, 200 Neb. 1, 11, 261 N.W.2d 766, 772 (1978); and Washington, see, e.g., Kammerer v. Western Gear Corp., 27 Wash. App. 512, 521-22, 618 P.2d 1330, 1337 (1980) (no punitive damages in absence of statutory authorization). See also N.Y.U. Note, supra note 33 , at 303 n.2.

3s By statute, Connecticut limits punitive damages in products liability cases to twice the amount of compensatory damages. Conn. Gen. Stat. AnN. § 52-240b (West Supp. 1981). See note 247 infra.

40 Except in certain limited situations. See Art Hill Ford, Inc. v. Callender, 423 N.E.2d 601 (Ind. 1981); see generally 5 A. CoRBIN, ConTracts $§ 1077$ (1964). Nor, as a result, are such damages generally available for breach of warranty. See U.C.C. \$ 1-106(1) (1978). See generally Owen, supra note 7, at 1271-77; Sullivan, Punitive Damages in the Law of Contract: The Reality and the Illusion of Legal Change, 61 Minn. L. REv. 207 (1977); Note, The Expanding Availability of Punitive Damages in Contract Actions, 8 IND. L. REv. 668 (1975); Comment, Punitive Damages on Ordinary Contracts, 42 Mont. L. REv. 93 (1981).

41 Such damages are not available in wrongful death actions unless a statute expressly or by clear implication so provides. See, e.g., Wangen v. Ford Motor Co., 97 Wis. $2 \mathrm{~d} 260$, 311-15, 294 N.W.2d 437, 463-65 (1980). Also suing Ford in Grimshaw were the heirs of the driver of the accident vehicle who were denied their claims for punitive damages for wrongful death. See 119 Cal. App. 3d at 824-36, 174 Cal. Rptr. at 392-99. The constitutionality of the denial was unsuccessfully challenged on equal protection grounds in Grimshaw, id. at 832-63, 174 Cal. Rptr. at 397-99, as it has been in other recent cases; see In re Paris Air Crash, 622 F.2d 1315 (9th Cir.), cert. denied, 449 U.S. 976 (1980); Huff v. White Motor 
of other limitations on their availability. ${ }^{42}$ Punitive damages are permitted by various state and federal statutes (and by constitutional provision in some states) for a variety of wrongs, sometimes in the form of double, treble, or quadruple damages. ${ }^{43}$

The amount of a punitive damages award in most states is left to the discretion of the jury, which considers the seriousness of the defendant's misconduct, the nature and extent of the plaintiff's injury (as measured by the compensatory damages), and the "wealth" of the defendant (on the theory that it takes more to punish a rich man than a. poor one)."4 Some states require that such an award bear a reasonable relationship in amount to the compensatory award, ${ }^{45}$ but this rule is often applied flexibly so that ratios of thirty to one or higher are sometimes approved. ${ }^{16}$

Punitive damages have been the subject of substantial criticisms by some courts and commentators for many years. In addition to the absence of criminal law procedural safeguards in their application, such damages are criticized generally for being inconsistent with the civil law's focus on providing compensation for losses, for giving plaintiffs undeserved "windfalls," for having no objective standard for determining their propriety or amount in individual cases (which may make them largely unpredictable and effectively nonreviewable), and for being designed to deter misconduct when there is no good proof that they do."7 Yet punitive damages awards are a fixture of the civil law, dating back at least to

Corp., 609 F.2d 286 (7th Cir. 1979); Johnson v. International Harvester Co., 487 F. Supp. 1176 (D.N.D. 1980); Robert v. Ford Motor Co., 73 A.D.2d 1025, 424 N.Y.S.2d 747 (1980).

42 See Restatzaent, supra note 35,8908 comment $\mathrm{f}$.

43 See, e.g., Rivers v. Ex-Cell-O Corp., 100 Mich. App. 824, 300 N.W.2d 420 (1980) ( $\$ 450,000$ compensatory award required to be trebled under malicious prosecution statute). See also Comment, Punitive Damages Under Federal Statutes: A Functional Analysis, 60 CaLIF. L. RBv. 191 (1972). See generally Owen, supra note 7, at 1264-65 n.23.

14 See RestatzMENT, supra note 35, \& $908(2) \&$ comments b-e.

16 See, e.g., Maxey v. Freightliner Corp., 450 F. Supp. 955, 964-66 (N.D. Tex. 1978) (Texas law described but held not binding), aff'd, 623 F.2d 395 (5th Cir.), rehearing en banc granted, 634 F.2d 1008 (5th Cir. 1980); Thomas v. American Cystoscope Makers, Inc., 414 F. Supp. 255, 264 (E.D. Pa. 1976) (Pennsylvania law cited). See also Leimgruber v. Claridge Assocs., Ltd., 73 N.J. 450, 375 A.2d 652 (1977). See generally Comment, Punitive Damages and the Reasonable Relation Rule: A Study in Frustration of Purpose, 9 PAc. L.J. 823 (1978).

4e See, e.g., Maxey v. Freightliner Corp., 450 F. Supp. 955, 964-66 (N.D. Tex. 1978) (\$10 million punitive damages verdict, some 60 times greater than compensatory verdict for $\$ 150,000$, held within flexible ratio rule, as applied in Texas; punitive verdict stricken on other grounds), aff'd, 623 F.2d 395 (5th Cir.), rehearing en banc granted, 634 F.2d 1008 (5th Cir. 1980).

${ }^{47}$ See Owen, supra note 7, at 1267 n.41. 
the Code of Hammurabi of 2000 B.C., ${ }^{18}$ and criticisms notwithstanding they appear likely to remain in general use for some time.

\section{Punitive Damages in Products Liability Cases}

Products liability cases present a variety of problems that complicate the application of the traditional punitive damages rules. Several recurring issues in such cases are reviewed here briefly, and others will be examined in the parts that follow.

\section{A. Juror Limitations and Attitudes}

A jury trial presents difficulties for the fair administration of a complex products liability case, and the problems are aggravated by the presence in the case of a punitive damages claim. Plaintiffs do not by any means win all products liability cases, even for compensatory damages, and in fact the odds at present appear to favor the manufacturer when such cases go to trial. ${ }^{48}$ Yet a full explanation of the manufacturer's decision making process (which is on trial in a punitive damages case) is necessarily complex and somewhat dull, ${ }^{50}$ and jurors easily can become confused and bored by the technical evidence. Cases often drag on for weeks or even months, with one expert witness following another, ${ }^{51}$ and the interest, attention, and comprehension of many jurors often are left far behind. The engineering complexity of the typical design case is. multiplied considerably by the difficult concepts and issues of value added by the allegation of flagrant manufacturer misbehavior. The desirability of jury trial in other types of complex civil

48 See id. at 1262-64 \& nn. 17-23.

49 Studies of recent products liability case outcomes vary in their results, with defendants prevailing in 50-75\% or more of the cases. See W. KeEton, D. OWEN, \& J. Montgomery, Products Liability and Safety: Cases and Materials 28 (1980) [hereinafter cited as W. KEETON].

so See generally Henderson, Judicial Review of Manufacturers' Conscious Design Choices: The Limits of Adjudication, 73 CoLum. L. REv. 1531 (1973); Henderson, Should a "Process Defense" Be Recognized in Product Design Cases?, 56 N.Y.U. L. REv. 585 (1981) [hereinafter cited as Process Defense]; Twerski, Weinstein, Donaher, \& Piehler, Shifting Perspectives in Products Liability: From Quality to Process Standards, 55 N.Y.U. L. REv. 347 (1980) [hereinafter cited as Twerski, Shifting Perspectives]; Weinstein, Twerski, Piehler, \& Donaher, Product Liability: An Interaction of Law and Technology, 12 DuQ. L. Rev. 425 (1974).

s1 Products liability cases frequently involve hundreds of photographs, exhibits, and films and often resolve down to a battle of the experts. See, e.g., Jenkins v. General Motors Corp., 446 F.2d 377, 380-81 (5th Cir. 1971), cert. denied, 405 U.S. 922 (1972). See generally W. KeETon, supra note 49 , at 56-58 \& nn.1-3. 
litigation presently is under reconsideration by some courts ${ }^{52}$ and commentators; $^{\text {s3 }}$ it may be that the debate should be broadened to include complex products liability cases, particularly those involving claims for punitive damages. ${ }^{54}$

In addition to problems of comprehension, jurors have a natural sympathy for a seriously injured person that is reinforced when the defendant is a manufacturer, ${ }^{, b}$ for many persons are hostile toward major institutions in general and "big business" in particular. ${ }^{.8}$ Some jurors may thus be tempted to resort to simplistic explanations of the issue (such as that the defendant callously "traded lives for dollars") that comport with their preconceived notions of manufacturers' oppression of consumers.

Such preconceptions may generally be tolerable in determining compensatory liability. Because most companies are insured against such losses, ${ }^{67}$ and because they have greater access to much of the crucial evidence and greater financial resources with which to defend their cases, a little bias in favor of compensating the injured user of a product may in fact be good. For even if a "closecall case"ss is "wrongly" rendered for the plaintiff, his suffering

${ }^{32}$ Compare Cotten v. Witco Chem. Corp., 651 F.2d 274 (5th Cir. 1981) with Matsushita Elec. Indus. Co. v. Zenith Radio Corp., 631 F.2d 1069 (3d Cir. 1980).

ss See, e.g., Arnold, A Historical Inquiry Into the Right to Trial by Jury in Complex Civil Litigation, 128 U. PA. L. REv. 829 (1980); Devlin, Jury Trial of Complex Cases: English Practice at the Time of the Seventh Amendment, 80 Covum. L. Rkv. 43 (1980); Edquist, The Use of Juries in Complex Cases, 3 CoRp. L. Rsv. 277 (1980); Jorde, The Seventh Amendment Right to Jury Trial of Antitrust Issues, 69 CALIr. L. Rsv. 1 (1981); Note, The Right to a Jury Trial in Complex Civil Litigation, 92 HARv. L. REv. 898 (1979); Note, Preserving the Right to Jury Trial in Complex Civil Cases, 32 Stan. L. Rzv. 99 (1979); Note, Complex Civil Litigation: Reconciling the Demands of Due Process with the Right to Trial by Jury, 42 U. PrTT. L. REv. 693 (1981); Annot., 54 A.L.R. Fen. 733 (1981).

st Bifurcation of the punitive damages issues at trial, separating the functions of jury and judge, is discussed below. See text and notes at notes 244-251 infra.

${ }^{s 5}$ See, e.g., note 61 infra.

se This negative bias is fed by the television media, which usually portray businessmen as foolish, greedy, or criminal. See The Madia Institute, Crooks, Conmen and Crowns: Businessmen IN TV EnTERTainment (L. Theberge ed. 1981). The study concluded:

The business world in general is portrayed in a rather curious light-as the embodiment of all that is wrong with American capitalism. Bosses reap major rewards at the expense of both their workers and the general public. The interests of business are unalterably opposed to those of working people and consumers. What is good for business is not likely to be in the interest of American society.

Id. at 32 .

${ }^{87}$ Increasingly, however, the high cost of products liability insurance is forcing manufacturers to self-insure, at least to the extent of accepting considerably higher deductibles and lower limits. See generally TASK Force Final REPORT, supra note 32, ch. VI.

84 This apt descriptive phrase is used by Twerski, Shifting Perspectives, supra note 50, at 384. For a fuller discussion, see the classic rock tubs analysis in Henderson, Process De- 
will be lessened, and the institutional "suffering" of the manufacturer will be limited to the amount of the plaintiff's actual loss, his compensatory damages. Only infrequently, and only in a few jurisdictions, will such "wrong" decisions against a manufacturer reach one million dollars. ${ }^{58} \mathrm{We}$ thus may wish to tolerate, and perhaps be able to afford, a little such compassion at the expense of some efficiency. ${ }^{60}$ The stakes are increased considerably, however, in both principle and amount, when claims are made for punitive damages. The presence of such claims places a premium on the oratorical and other trial skills of counsel in products cases, raising a special risk of tapping juror bias that may test the limits of fair adjudication. ${ }^{\text {(1 }}$

fense, supra note 50.

B9 This is not to say that million dollar awards are rare in products cases; such awards are becoming more frequent. My hypothesis here is that the improper assessment of such high awards is infrequent. Although the figures are now somewhat dated, studies relied upon by the federal Interagency Task Force in 1976-77 showed the average award to be $\$ 222,000$ for the period 1971-76. See W. KeEton, supra note 49, at 28.

${ }^{\circ}$ But cf. Owen, supra note 31, at 703-07 (questioning compassion as a proper basis for shifting losses in a world of scarce resources).

i1 One plaintiffs' lawyer, Gerry Spence of Jackson, Wyoming, demonstrates the point. Although he "regularly takes on the polished lawyers who represent powerful corporations," he reportedly has not lost a jury case in twelve years. Trme, Mar. 30, 1981, at 48. Spence represented the interests of Karen Silkwood in the plutonium contamination case of Silkwood v. Kerr-McGee Corp., 485 F. Supp. 566 (W.D. Okla. 1979), rev'd in part, No. 791894 (10th Cir. Dec. 11, 1981), where the jury awarded $\$ 10$ million in punitive damages, and a former Miss Wyoming in her libel case against Penthouse magazine, where the jury awarded damages, mostly punitive, of $\$ 26.5$ million. True, Mar. 30, 1981, at 48. "Says one of Spence's victims: 'He's so good that he shouldn't be permitted in a courtroom.' "Id.

Another such lawyer may be Sheldon Schlesinger, "recognized by his peers as one of the best, if not the best trial lawyer in Broward County," Florida. Fort Lauderdale News \& SunSentinel, Sept. 13, 1981, at 11B, col. 1 (emphasis in original). Mr. Schlesinger, a member of the Inner Circle of Trial Lawyers who has won "five or six" verdicts of at least $\$ 1$ million, $i d$. at col. 2 , recently won a $\$ 5$ million verdict (including $\$ 3$ million in punitive damages) in a Toyota crashworthiness case brought for the deaths of three sisters. See Moll v. Toyota Motor Co., No. 79-17458 (Cir. Ct., Broward Cty., Fla., Sept. 8, 1981). Schlesinger's "courtroom style" in the case reportedly "could best be described as bordering on uncontrollable emotional frenzy." Fort Lauderdale News \& Sun-Sentinel, Sept. 13, 1981, at 11B, col. 1. One episode during the trial was described as follows:

The quintessential Schlesinger-extracting pathos from statistics-emerged when Toyota called witness B.J. Campbell, director of the Highway Safety Research Center at the University of North Carolina.

Campbell testified he had studied 1,047 rear-end collisions involving 1971-73 Toyota Coronas in North Carolina, South Carolina, Maryland and New York-the only states from which he could get complete statistics.

Of those 1,047 accidents, none involved fires, Campbell said, so the Corona appears to be as safe as any other car.

On cross-examination, Schlesinger leaped to his feet, bouncing in excitement, his ferret eyes gleaming. 
B. Changing Social Values and Economic Conditions Over Time

Certain effects of the "time dimension" in products cases have been examined recently by Professor James Henderson, ${ }^{62}$ and these problems have particular relevance to punitive damages claims. A product may be designed in one decade, manufactured and sold in the next, and produce injury in another; a suit involving the product may go to trial in the next decade, and perhaps not be reviewed on appeal until yet another decade has begun. ${ }^{63}$ In Grimshaw, for example, the Pinto was designed in the 1960's, the car at issue was made and involved in the accident in the early 1970's, the trial was held in 1977 and 1978, the first appeal was decided in 1981, and the case goes on. ${ }^{64}$ Before the case is finally resolved, an entire generation may have passed. Nor are substantial time delays uncommon in products litigation; a case where the design and final appeal both take place in the same decade may today be more the exception than the rule. ${ }^{65}$

The problem, of course, is that society's values concerning safety and corporate responsibility have been evolving rapidly in recent years. ${ }^{68}$ It is one thing to judge according to today's higher standards the "safety" or "defectiveness" of a product that was

\footnotetext{
"Denise Moll! Pamela Moll! Wendy Moll!" he thundered. "They were not even a statistic in your data bank! They were not even a statistic in your data bank!"

Using timing and tone of voice any actor would envy, Schlesinger reeled off eight rear-end collisions in which Coronas caught on fire in California. Seven people died.

After relating each victim, Schlesinger demanded of Campbell, "Was that part of your statistics?" Each time, Campbell quietly answered no.

Outside the courtroom, Rumberger [Toyota's lawyer] paid tribute to his opponent's ability to sway the attentive, four-man, two-woman jury-which includes a retired milkman, a vending machine serviceman and an ex-mechanic-and said the case may well turn on that.

"If you take the sympathy out of this case, they've got nothing," he said. "But as long as there's sympathy there, it's very, very serious."
}

Miami Herald, Aug. 30, 1981, at 4B, cols. 5-6.

22 Henderson, Coping with the Time Dimension in Products Liability, 69 Calip. L. RBv. 919 (1981). See also Phillips, An Analysis of Proposed Reform of Products Liability Statutes of Limitations, 56 N.C.L. REv. 663 (1978) [hereinafter cited as Proposed Reform]; Phillips, The Standard for Determining Defectiveness in Products Liability, 46 U. CIN. L. REv. 101, 115-19 (1977).

os The problem has been particularly severe for manufacturers of industrial machinery, such as punch presses, that may last for several decades. See, e.g., TASK Force Final REPORT, supra note 32 , at VII-22.

See 119 Cal. App. 3d at 773-79, 174 Cal. Rptr. at 359-63.

os But cf. Phillips, Proposed Reform, supra note 62, at 664-65 nn.10 \& 11 (citing studies that suggest most products liability actions do not involve older products).

ss See generally Owen, supra note 31 , at 705 . 
made when concern for safety was much less, and to compensate a victim accordingly for losses actually suffered. It is quite another to exact enormous "punishment" from an enterprise, acting on our greater social consciousness of today, for decisions that were made pursuant to business ethics of times past by men and women who since have left the company ${ }^{67}$ and perhaps this life. In our zeal to punish abuses discovered today, we must be cautious not to overlook the prevailing moral and business standards of the time involved.

Another serious problem in these cases is that the financial health of an enterprise may change substantially during significant phases of the lawsuit. Ford Motor Company, for example, reported record earnings of $\$ 1.67$ billion for 1977 within days after the Grimshaw jury returned its $\$ 125$ million punitive damages verdict in early $1978 . .^{88} \mathrm{By}$ the time the appellate opinion was issued in 1981, however, the fortunes of the automobile industry had changed dramatically, and for 1980 Ford reported record losses of $\$ 1.54$ billion. $^{69}$ Although such drastic changes in the financial health of the enterprise being punished may not be sufficient under current legal doctrine to open a punitive damages judgment on the ground of newly discovered evidence, ${ }^{70}$ such changes demonstrate another problem of permitting multi-million dollar awards of punitive damages. ${ }^{71}$

e7 For example, Lee Iacocca, the driving force behind the Ford Pinto, see Grimshaw v. Ford Motor Co., 119 Cal. App. 3d 757, 774, 174 Cal. Rptr. 348, 360 (1981), is now president of Chrysler Corporation.

68 See Wall St. J., Feb. 17, 1978, at 4, col. 1.

69 See id., May 15, 1981, at 2, col. 2. For 1981, Ford reported losses of $\$ 1.06$ billion. Wall St. J., Feb. 19, 1982, at 7, col. 1. Likewise, International Harvester Company, a defendant in several punitive damages cases, see, e.g., Stambaugh v. International Harvester Co., No. 76-L-2775 (Cir. Ct., St. Clair Cty., Ill., Oct. 26, 1979), is experiencing severe financial difficulties at the present time. Its losses from operations for the year ending October 31 , 1981 , could exceed $\$ 500$ million, Wall St. J., Sept. 8,1981 , at 11, col. 1, and it soon may face bankruptcy or acquisition, see id., Sept. 21, 1981, at 1, col. 6 .

70 Such changes probably are not sufficient to open up such judgments because "the evidence must have been in existence at the time of the trial ..."11 C. WRIGHT \& A. Miller, Federal Practice and Procedure § 2859, at 182 (1973). See Fed. R. Civ. P. 60(b)(2).

${ }^{71}$ There are two additional aspects of the time dimension that present particular problems to manufacturers in the punitive damages context. The first is inflation, which in retrospect makes safety improvements passed by in former years look especially inexpensive by today's standards. In Grimshaw, for example, the court appeared impressed by the "cheapness" of the various design "fixes," which had ranged in projected cost at the time from $\$ 1.80$ to $\$ 9.95$ per car. See note 149 infra. Yet the "inexpensiveness" of such design changes must be viewed against the fact that Ford designed the car to sell for a total price 


\section{Problems with Punishing a Manufacturing Entity}

Punitive damages were developed largely as a punishment and deterrent for trespassers, oxen thieves and other such human malefactors. ${ }^{22}$ When the device is transferred to the complex bureaucracy of a modern manufacturing concern, the fit is awkward in many respects. Final "decisions" concerning a complex product are often the result of a splintered, bureaucratic process involving a complicated combination of human judgments made by scores of persons at different levels in the hierarchy who pass on different aspects of the problem at different times. Various engineers may have to rely upon the work of research chemists, physicists, and other scientists; input from the financial and marketing arms of the enterprise must be factored in along the way. The entire process may take years. ${ }^{73}$ Each of these human actors makes decisions based on his own motives and on different types and amounts of information, and even the responsible executive at the end of the decisional line can possess only a small bit of the total information involved. Moreover, the corporate owners of the enterprise are usually far removed from most decisions of even the top executives.

This is not to say that institutional safety procedures cannot be put in place and monitored to ensure that safety gets its day in the manufacturer's decisional court, and the modern company without procedures of this type should be held to some account.74

of only $\$ 2,000$. See 119 Cal. App. 3d at 774, 174 Cal. Rptr. at 360 .

Another problem often overlooked is the institutional lethargy inherent in any large bureaucracy. It simply takes a good deal of time for a large institution to perceive and understand the nature of a safety problem, to study whether it can be remedied feasibly, and to decide upon and then to accomplish a corrective course of action. In at least two recent cases, courts have appeared insensitive to this problem. See Cantrell v. Amarillo Hardware Co., 226 Kan. 681, 687, 602 P.2d 1326, 1331 (1979) (citing continued manufacture and marketing of stepladder for "many months" after notice of ladder's weaknesses); Wussow v. Commercial Mechanisms, Inc., 97 Wis. 2d 136, 152-56, 293 N.W.2d 897, 905-07 (1980) (finding no attempt to warn prior purchasers or to add product safety features during year following the acquisition of manufacturer by successor corporation).

${ }_{72}$ Apparently the first reported American case allowing punitive damages was Genay v. Norris, 1 S.C.L. (1 Bay.) 6 (1784), where the defendant, a doctor, added a large quantity of cantharides (Spanish fly) to the plaintiff's glass of wine as a practical joke.

7s The period between initial conception to production of a new model car has been estimated to average 43 months. See Dowie, supra note 2, at 20-21. Although the Pinto's development is said to have been cut to under 25 months to meet quickly the competition from foreign small car imports, $i d$., a Ford document shows that the actual period of development was between these two points, see Ford Motor Company, North American SubCompact Car Study (1969) (on file with The University of Chicago Law Review).

74 This was a central thesis of my earlier article. See generally Owen, supra note 7, at 1325-61. 
Yet we must remember that the concepts of moral responsibility, punishment, and deterrence can mean vastly different things when judging the "conduct" of an institution rather than of a human being. ${ }^{75}$

The serious difficulty of attempting to apply human standards of culpability to manufacturers in this context is highlighted by the problem of defining the proscribed misconduct, ${ }^{76}$ an issue that will be examined at length below. The problem in capsule form is simply this: humans are clearly culpable when they act to gain a minor advantage in a way they know will be likely to kill or injure others. Thus, we usually punish a person who deliberately or recklessly kills or maims another without good reason. Yet manufacturers of hazardous products such as automobiles (which kill and maim thousands every year) must design them in many different ways they know with virtual certainty will result in harm or death at some time to a certain number of unfortunate, statistical persons. In a sense, then, such manufacturers always act "intentionally" in derogation of human life, yet surely punishment is inappropriate for simply being in the business of making high speed machines. ${ }^{77}$

\section{Documentation of Design Process Decisions}

The key to winning a punitive damages case against a manufacturer is often said to lie in finding a "smoking gun" in the defendant's files. ${ }^{78}$ The "powder keg" memorandum, for example, was pivotal in the Gryc flammable fabrics case, ${ }^{79}$ as was Ford's

76 See authorities cited infra note 217.

76 See generally Landes \& Posner, An Economic Theory of Intentional Torts, 1 INT'L REv. L. \& ECON. 127, 139, 148-50 (1981); see also text and notes at notes 93-125 infra.

77 See text and notes at notes 105-119, 139 infra.

${ }^{78}$ See J. Fetterly, Trial Strategy Considerations in Presenting a Punitive Damage Claim in a Products Liability Case: The Plaintiff's Perspective 1 (Aug. 15, 1979) (unpublished paper delivered to the Section on Insurance, Negligence, and Compensation Law, ABA Annual Meeting, Dallas, Tex.) (on file with The University of Chicago Law Review). Fetterly, it should be noted, represented the plaintiff in Chastain v. Lymndale Int'l, Inc., No. CIV-80-23 (Cir. Ct., Cleburne Cty., Ark., Sept. 4, 1981), in which the jury awarded punitive damages of $\$ 3$ million. He also recovered a total of $\$ 900,000$ in punitive damages against Celotex Corporation (also the defendant in Chastain) and Dow Chemical Company in Oakhurst, Inc. v. Tasco, Inc., No. 27,015 (Dist. Ct., Freeborn Cty., Minn., Jan. 19, 1978) (order denying post-trial motions and providing for stay).

${ }^{79}$ Gryc v. Dayton-Hudson Corp., 297 N.W.2d 727, 734, 740 (Minn.), cert. denied, 449 U.S. 921 (1980). This was an internal memorandum, entitled "Flammability-Liability," written in 1956 by one of the textile manufacturer's top officials: "We are always sitting on somewhat of a powder keg as regards our flannelette being so inflammable." "Id. at 734 . 
cost-feasibility memorandum-examining various design improvements for the Pinto fuel system-in the Grimshaw case ${ }^{80}$ On rare occasions such documents may in themselves prove a callous disregard by corporate executives of human health or safety. ${ }^{\mathbf{8 1}}$

In many cases, however, there are significant dangers of abuse in the manipulation of documentary evidence. Manufacturers necessarily create massive documentation of their design and production processes, ${ }^{82}$ sometimes amounting to millions of pages of notes, memoranda, and correspondence over the life of a product. Especially during the initial design of the product, but also as information returns on the product's performance in the field, reports of many instances of one problem or another will be documented, acted upon, and filed away. In fact, the more a manufacturer is truly concerned about its product's safety, the more it will encourage self-criticism and "negative" analyses of the product within the company. ${ }^{83}$ For example, it often is desirable during the

80 This was a "Fuel System Integrity Program Financial Review" report considered at a product review meeting in April 1971 (Exhibit 125) that examined the financial impact of alternative methods of meeting a proposed federal standard on fuel system integrity and the cost savings that would result from deferring such modifications. See 119 Cal. App. 3d 757, 777-78 n.2, 174 Cal. Rptr. 348, 361-62 n.2. The report estimated cost savings from deferral at $\$ 100$ million, a calculation that was highlighted in the plaintiff's closing argument and that apparently formed the basis for the jury's $\$ 125$ million award. See Opening Brief for Appellant Ford Motor Co., at 30-31, Grimshaw; note 243 infra.

See also Rimer v. Rockwell Int'l Corp., 641 F.2d 450, 455 (6th Cir. 1981) (memo revealing that aircraft manufacturer knew of fuel cap siphoning problem but chose not to issue service bulletin because it feared that litigation would thereby be encouraged); $M$. Johnston, The Last Nine Minutes: The Story of Flight 981, at 234-37 (1976) (discussing the "Applegate memo" predicting that the cargo door could detach from a DC-10 and cause the loss of the plane). See generally Owen, supra note 7, at 1356-57 nn.478 \& 479.

s1 See Westin, Introduction to Whistle Blowing! Loyalty and Dissent in the CorpoRATION 11 (A. Westin ed. 1981) (noting documents purportedly showing that asbestos manufacturers suppressed information on hazards of asbestosis).

s2 See generally Twerski, Shifting Perspectives, supra note 50, at 369-72.

83 One may postulate that the most safety-conscious manufacturer will direct its employees to search out and investigate even remotely possible dangers, to explore even barely plausible remedial measures, and to document the possibilities that dangers may be present and cured. Among the range of dangers and remedies so documented, a manager with "due" regard for consumer safety will act to reduce or eliminate such risks only to the extent that it is reasonable to do so. Such a manager may therefore "consciously" yet reasonably choose to leave in the product remote dangers that are too expensive to remove, and sometimes even substantial dangers for which there is no practicable remedy. The documentation of such a choice should not, of course, support a punitive award.

Another dimension of this problem concerns the variety of psychological make-ups of the manufacturer's employees. The employees of a large manufacturing concern will entertain a broad spectrum of diverse political and practical viewpoints on how much safety is enough. At one extreme may be an engineer or marketing person who will decry any loss of utility for safety, while at the other extreme may be an employee to whom safety is para- 
initial stages of a product's design to test it to its limits to discover what those limits are: cars may thus be crash-tested until their gas tanks burst, and rats may be injected with a drug in ever higher doses until some die. ${ }^{84}$ Documentary evidence (especially films) of such tests can later return to haunt the manufacturer, as they did in the Grimshaw Pinto case. ${ }^{85}$ Such a manufacturer, constantly striving to uncover sources of weakness in and dissatisfaction with its products to produce an ever better product for the public, may thereby create the documentary seeds for a punitive damages claim in a future products suit. ${ }^{86}$

In the documentary background of most inherently dangerous products will be some fair number expressing concern over many of the significant choices in the design process. ${ }^{87}$ The lesson for a plaintiff's lawyer facing a warehouse full of documents in a prod-

mount. One might characterize the persons at these extremes as "alarmists": the "utility alarmists"-who characteristically will criticize the prototype or final product as "too safe," and the "safety alarmists"-who characteristically will find an "excess" of danger. While memoranda from either type of alarmist will likely appear incriminating after a product accident years later, the conscientious manufacturer may find the dialectical presentation of such extreme viewpoints especially useful in establishing a counterpoint for informed decision making, somewhere toward the center of which will usually lie the "correct" decision as to the level of safety. Tribunals must be cautious, therefore, not to place excessive weight on internal memoranda criticizing product safety performance or proposing (or questioning) improvements, for the source of such criticism may have been an alarmist whose advice was properly rejected after due consideration. Although such documentation may, of course, be highly relevant to the culpability issue, it will usually represent only a part of the much larger puzzle of institutional motivation and rationale. Cf. Dorsey v. Honda Motor Corp., 665 F.2d 650, 653 (5th Cir. 1981) (noting Honda's rejection of an employee's proposal to enlarge the car's size or strength to increase safety).

84 See M. Dixon, Drug Product Liability § 6.05 (1980); W. Lowrance, Of Acceptable Risk 64-70 (1976).

${ }^{85}$ One piece of evidence that made a particular impact on the jury in Grimshaw was Exhibit 122, a motion picture showing a prototype Pinto being crash tested. When the vehicle was backed into a fixed barrier at 21.5 miles per hour, "the filler neck of the fuel tank separated allowing fluid to spill from the tank." 119 Cal. App. 3d at 791, 174 Cal. Rptr. at 370. A juror who was interviewed shortly after the verdict pointed to the dramatic impact this film had made at trial: "The gas tank, filled with a nonflammable substance, ruptured with such force . . . that 'it looked like a fireman had stuck a hose inside the car and turned it on." "Wall St. J., Feb. 14, 1978, at 1, col. 4. Ford's objections to the relevance of the film, a particularly sensitive issue in view of the substantial prejudice it obviously was bound to engender, were based upon the fact that the Grimshaw car's filler neck did not separate, unlike the crash test car. These objections were rejected by the court. 119 Cal. App. 3d at 791, 174 Cal. Rptr. at 370.

86 See O'Donnell, Design Litigation and Strict Liability: The Problem of Jury Instructions Which Do Not Instruct, 56 U. DET. J. UrB. L. 1051, 1067 (1979).

${ }^{87}$ In fact, the Twerski group recently proposed a "process defense" predicated on the creation and retention of documents of all such choices made. See Twerski, Shifting Perspectives, supra note 50 , at 369-72. 
ucts case is clear. A skillful plaintiff's lawyer will often be able to find and string together a series of such documents, plucked from context among the thousands or millions in the company's files, that may make the manufacturer look particularly insensitive to consumer safety and more concerned about cutting costs. Although the role of defense counsel is of course to explain away such documents, when a fair response can be made, the risks of abuse-and the necessity for close judicial supervision-appear especially great in this regard. By adopting appropriate safeguards against documentary abuse, the courts can help prevent manufacturers from being discouraged from generating and retaining ${ }^{88}$ complete records of a product's development, and thereby they can also advance the goals of product safety and compensation in proper suits.

\section{E. Measuring Wealth and Poverty}

Because the defendant's wealth is a relevant factor in determining the amount of punitive damages, ${ }^{80}$ one must inquire what "wealth" really means in the case of a manufacturing entity. Basic financial sheet data such as sales, profits, and net worth most often have been regarded as the relevant indicators of a corporation's "wealth." lated to a company's true financial prosperity, for very little of the gross earnings remains-even when times are good-after deducting the costs of materials, labor, sales, administration, taxes, and, increasingly, the cost of capital. Even profits after taxes are plainly not idle wealth, because the enterprise will fail if the owners do not receive a fair return on their investment. And even after the payment of dividends, although such retained "profits" may travel to the balance sheet adding to net worth, the remaining dollars hardly represent a pot of idle gold, ripe for plucking by the plain-

ss The practical, legal, and ethical considerations involved in designing and implementing corporate programs for document control-including creation, circulation, supervisor and counsel review, alteration, supplementation, storage, surrender, and destruction-are topics of especially great interest to in-house counsel and outside defense lawyers at current continuing legal education programs on punitive damages. See, e.g., ABA National Institute on the Trial of Punitive Damages Cases, Apr. 25-26, 1980 (L.A.), May 23-24, 1980 (Boston), May 29-30, 1981 (N.Y.). See generally Fedders \& Guttenplan, Document Retention and Destruction: Practical, Legal and Ethical Considerations, 56 Notre Damz Law. 5 (1980); Note, Legal Ethics and the Destruction of Evidence, 88 YALE L.J. 1665 (1979).

s9 See RestatemENT, supra note 35, § 908(2).

o See Owen, supra note 7, at 1318 n.295. 
tiff and his lawyer, for usually they will be reinvested in plant, equipment, salaries, and other future costs of operation-"the costs of staying in business."'1 Moreover, a large assessment of punitive damages against an enterprise will affect at least to some extent its earnings, and hence, most likely, the value of its stock. ${ }^{92}$

These are difficult notions for juries to understand, and the sophistication of many judges on such matters also leaves much to be desired. The difficult job of education will fall squarely upon the shoulders of the defendant's financial experts, and the trial court will have to hold a tight rein on evidence and argument in this area where prejudice follows error with special ease. Yet even when the evidence and argument on these matters are beyond reproach, the multi-million (sometimes billion) dollar figures discussed at trial may all begin to blur in the minds of many jurors. If such be true, a typical juror may well be receptive to an argument that anything less than $\$ 1$ million would be but a drop in the bucket and that much more than that would be required to catch the attention of the company's executives and to teach them a lesson.

\section{Defining the Basis of Liability}

The place to focus initial inquiry for restricting abuses of the punitive damages doctrine is in the formulation of the test of punitive liability and in the types of evidence that go to meet that test. This part first examines the standard for liability and then considers the types of evidence to which courts have recently pointed as aggravating or mitigating the defendant's fault.

\section{A. The Liability Test}

One aspect of punitive damages doctrine in which remarkably little change has occurred in the past few years, yet one where re-

91 See P. Drucker, Managing in Turbulent Times 28-30 (1980).

92 The ripple effects through the affairs of an enterprise from a change in stock price may be extensive, possibly affecting the cost and availability of capital and acquisition opportunities.

Because the payment of a punitive damages judgment is ordinarily tax deductible to the corporation, the effect of such awards on after-tax earnings is reduced considerably. See Rev. Rul. 211, 1980-2 C.B. 57. Contrary to common sense and to common belief, see, e.g., Bus. Wk., Jan. 12, 1981, at 86 , punitive damages awards probably are not taxable to an individual when received on account of personal injuries. See Rev. Rul. 45, 1975-1 C.B. 47. See generally Note, The Tax Consequences of a Punitive Damages Award, 31 Hastings L.J. 909 (1980). 
finement is most needed, concerns the definition of the proscribed misconduct. I have previously recommended a standard of liability grounded upon the defendant's "flagrant indifference to the public safety,"93 a test that I still believe fits well the special circumstances of most products cases. Most courts, unfortunately, including the court in Grimshaw, have eschewed the "flagrant indifference" standard and have opted instead to apply the broader, more traditional liability standards, such as "willful," "wanton," "malicious," "conscious," or "reckless" disregard of the rights of others. ${ }^{94}$

The trial court's instruction in Grimshaw is probably the most unsatisfactory of any that I have seen and demonstrates the vital need to tailor the standard of liability closely to the manufacturing context. The trial court there instructed the jury that "malice" could be "inferred from defendant's conduct if the conduct was willful, intentional and done in conscious disregard of its possible

see Owen, supra note 7 , at 1367 .

" See, e.g., Dorsey v. Honda Motor Co., 655 F.2d 650, 658 (5th Cir. 1981) ("wantonness or recklessness or reckless indifference to the rights of others"); Rinker v. Ford Motor Co., 567 S.W.2d 655, 667 (Mo. Ct. App. 1978) ("complete indifference to or conscious disregard for the safety of others"); Wangen v. Ford Motor Co., 97 Wis. 2d 260, 308, 294 N.W.2d 437, 462 (1980) ("malice, vindictiveness, ill-will, or wanton, willful or reckless disregard of plaintiff's rights").

At least two courts have adopted the "flagrant indifference" standard. See Moore v. Remington Arms Co., 100 Ill. App. 3d 1102, 1115, 427 N.E.2d 608, 617 (1981); Leichtamer v. American Motors Corp., 424 N.E.2d 568, 580 (Ohio 1981). See also Ellis v. Golconda Corp., 352 So. 2d 1221, 1225 (Fla. Dist. Ct. App. 1977); Wussow v. Commercial Mechanisms, Inc., 97 Wis. 2d 136, 156, 293 N.W.2d 897, 907 (1980). Perhaps the failure of more courts to adopt the "flagrant indifference" standard reflects a reluctance to change established legal doctrine. Such a concern is misplaced, however, because the "flagrant indifference" standard is merely a refinement of the more general standards, designed to narrow and apply those standards to this type of litigation. See Moore v. Remington Arms Co., 100 Ill. App. 3d $1102,1115,427$ N.E.2d 608, 617 (1981).

${ }^{\circ 5}$ CAL. Crv. Code $\S 3294$ (a) (West Supp. 1981), which authorizes awards of punitive damages, provides as follows:

In an action for the breach of an obligation not arising from contract, where the defendant has been guilty of oppression, fraud, or malice, the plaintiff, in addition to the actual damages, may recover damages for the sake of example and by way of punishing the defendant.

Definitions of "malice," "oppression," and "fraud" were supplied by amendment in 1980. "Malice," which was the pertinent standard in Grimshaw, is defined by the amendment as follows:

"Malice" means conduct which is intended by the defendant to cause injury to the plaintiff or conduct which is carried on by the defendant with a conscious disregard of the rights and safety of others.

CaL. Crv. Code $\S 3294$ (c)(1) (West Supp. 1981). The amendment did not apply to Grimshaw, where the court invoked the common law instead. See 119 Cal. App. 3d at 807-18, 174 Cal. Rptr. at 380-87. 
result." The totally unacceptable import of this standard is that every actor could be held strictly liable thereunder for punitive, in addition to compensatory, damages for any consequence to any person that was contemplated in advance of any course of action.

Virtually all important actions involve some risks to some people, and responsible individuals and institutions give careful consideration to such risks before they act. It is fundamental to life in a dynamic world with an unpredictable future that one must proceed to act, notwithstanding the presence of some foreseeable risks, provided that the benefits of the contemplated action (or inaction) appear at the time to exceed the risks. ${ }^{97}$ If this basic tenet of risk-benefit analysis were not virtually the universal rule, life would grind nearly to a halt. Everyone employs this process hundreds of times each day, ticking off the balance of advantages versus disadvantages (which may affect other persons adversely) of one choice after another, often in only fractions of a second. The

96 119 Cal. App. 3d at 815, 174 Cal. Rptr. at 385. Formulation of the standard of liability was supplemented in the trial court's instructions by other phrases of arguable opprobrium, such as "motive and willingness . . . to injure," "willful" and "intentional," as noted by the court of appeal. See id. at 817, $174 \mathrm{Cal}$. Rptr. at 387. Yet the phrase "conscious disregard of its possible result" clearly was the dominant phrase and concept in the instruction, and so its legitimacy and import fairly may be examined in isolation.

${ }^{97}$ There has been a resurgence in the last few years of the debate over the moral and political legitimacy of cost-benefit (or efficiency) analysis. Some of the more recent articles appear in a symposium in 8 Hofstra L. REv. 485 (1980), and a response thereto in id. at 811. At bottom, many of the issues boil down to whether and when the greater interests of one person or group should be promoted at the expense of the lesser interests of another, and how the values to be accorded such interests should be calculated. In social decision making, there are of course extremely difficult problems in measuring ("monetizing") and comparing what are sometimes incommensurable assets and values, and certain "rights" by definition should be held off limits to any scales. Yet life will continue to move forward despite such hard decisions, and its "tragic choices" must be faced and somehow made. See generally G. Calabresi \& P. Bobbitr, Tragic Choices (1978).

In the products liability context, the fundamental question often involves a choice between the interests of consumers in cheaper and more functional products versus the interests of persons who may be injured by those products in receiving protection against and compensation for such losses. Whether the legal level of product safety (the "defect" line) is set at the point of cost-efficiency or somewhere else, the interests of persons injured by product dangers falling on the no-liability side of the "defect" line are subordinated to the interests of consumers as a group. A major value that appears to fall outside narrow costefficiency analysis, but one that nevertheless receives substantial protection in products liability law (through the expectancy definition of defectiveness and requirements of warnings of, and perheps design protection against, hidden dangers) is the individuality of persons seeking to lead autonomous lives free from unexpected interruption. There is often a tension between these interests of efficiency and autonomy in products cases, a problem of fundamental importance that must be addressed in the years ahead. See generally Owen, supra note 31 . 
rules of negligence law provide that an actor generally will not be liable even for compensatory damages unless the balance of tradeoffs was a bad one-that is, one in which the $\operatorname{costs}^{88}$ exceeded the benefits, thus making the action on balance cost-ineffective. ${ }^{99}$ Punishment for such decisions usually can be justified only when the actor not only made the wrong decision but also made a deliberate choice to advance his good over what he knew to be the greater good of others. ${ }^{100}$ The trial court's instruction in Grimshaw is thus palpably in error, as it justifies punishment for most significant decisions even if made in all good faith, and even if on balance good. ${ }^{101}$

The court of appeal recognized one facet of the instruction's weakness in holding that "the rule should be expressed in terms of probability of injury rather than possibility," although it concluded that the error was harmless. ${ }^{102}$ The standard employed by the court of appeal, " 'conscious disregard' of the probability of injury to members of the consuming public,"10s is better than the trial court's instruction, because it more clearly provides that the contemplated conduct must be likely to cause some harm. This formulation of the standard nevertheless fails to address the central fact that the essence of sound engineering requires that manufacturers give careful consideration to the balance of risks and benefits perceived. The fact that the word "disregard" obliquely may contemplate a mental state of culpable indifference does not solve the problem. The decision to market a product in a certain condition with certain risks may have been a good one because the expected benefits were great, and the product may not have been legally defective at all, yet under this standard the manufacturer remains subject to punishment for "disregarding" the lesser risks by proceeding to sell the product with any danger whatsoever. ${ }^{104}$

os Negligence law, strictly speaking, speaks in terms of foreseeable "risks" rather than "costs." See generally W. KEETON, supra note 49, at 59-62, 238-51. The process perhaps most usefully may be described as a "cost-cost" analysis: comparing the cost of accidents to the cost of accident prevention. See Posner, A Theory of Negligence, 1 J. Legal Stud. 29 (1972).

99 See, e.g., Posner, supra note 98, at 32 .

${ }^{100}$ The manufacturer's "state of mind" is stated subjectively here to make the point more clearly. See text and notes at notes 108, 123 infra.

101 See generally Landes \& Posner, supra note 76, at 134 (case 4).

102119 Cal. App. 3d at 816-18, 174 Cal. Rptr. at 386-87.

${ }^{103}$ Id. at 813,174 Cal. Rptr. at 384.

104 The anomaly then would result that punishment would be authorized for conduct deemed good by compensatory liability principles, an outcome at odds with logic and well- 
The principal fault with the "conscious disregard" portion of the Grimshaw court's standard, then, is that it does not sufficiently limit the area of proscribed misconduct. As discussed above, a careful manufacturer should indeed be "conscious" of all foreseeable and significant risks that necessarily result from the difficult design trade-off decisions required to produce affordable products that work well. ${ }^{105}$ All we should ask of manufacturers through any legal rule is that all unreasonable dangers be removed from such products, not that all products be made completely safe. A manufacturer thus can be punished fairly only for knowingly leaving in its products dangers that are unreasonable-not for leaving in expected dangers that are too expensive to remove. ${ }^{106}$

The appellate court in Grimshaw referred at least twice in passing to Ford's "callous" disregard or indifference to safety; ${ }^{107}$ many of the problems outlined above would be solved if such a term were adopted as the principal standard of liability. An actor could not be said to be "callous" for proceeding to act in the face of known risks unless the benefits to the actor expected to flow from the conduct were known or strongly suspected to be less-perhaps much less-than the expected harms to others. Nevertheless, although "callous" may thus be an apt word to describe especially culpable decisions of human actors, "flagrant" is probably better suited to institutional misconduct. "Flagrant" implies an objective standard apart from the actor ${ }^{108}$ and indicates that, typically, only extreme departures from the norm, from accepted and acceptable safety practices and engineering choices, will subject the manufacturer to punishment. ${ }^{109}$

Cost-benefit analysis is fundamental to the design engineer's trade. ${ }^{110}$ The depth of the rubber on an automobile's bumper forever may be increased by another one-tenth inch. One more crossbeam always may be added to protect the occupants in certain

established doctrine. See RESTATEMENT, supra note 35 , § 908(1) comment b (for a punitive damages claim to lie, "a cause of action for the particular tort must exist").

${ }^{105}$ See text at note 77 supra.

${ }^{108}$ See text and notes at notes 98-100 supra.

${ }_{107} 119$ Cal. App. 3d at 813, 819, 174 Cal. Rptr. at 384, 388.

${ }^{108}$ For a variety of good reasons, objective proof of the manufacturer's apparent attitude toward consumer safety is a preferable standard to requiring subjective proof of the company's "state of mind." See Owen, supra note 7, at 1368; see also note 123 infra.

${ }^{109}$ See text and notes at notes 124, 174 infra. Awareness of wrongdoing can fairly be imputed to the manufacturer "when its conduct is obviously and seriously wrong." See Owen, supra note 7 , at 1369 .

110 See authorities cited supra note 50. 
types of collisions. The configuration of crossbeams may be changed to increase their strength; thicker or harder steel may be used in the beams; perhaps they may be made of another metal, or perhaps even of a form of plastic. Many hundreds of such choices are made by design engineers in the production of a single complex product, and each such decision involves a range of trade-offs between cost, weight, appearance, performance capabilities (for separate functions in varying environments), and safety in one type of accident versus another. ${ }^{111}$ A steel beam that protects an occupant in one type of accident may endanger him in another, as by rendering that portion of the vehicle less energy absorbent, and may endanger pedestrians and the occupants of other vehicles as well. ${ }^{112}$ Although much of this decision making involves the application of proven scientific principles, much is art, and some by its nature can be little more than trial and error.

There is an increasing appreciation among courts ${ }^{113}$ and commentators ${ }^{114}$ of the inherent difficulties in judging the adequacy of such complex design decisions in determining liability for compensatory damages. The courts must be even more vigilant to prevent punitive awards from intruding too deeply into the heart of American industry. Many of our most important products, from airplanes, cars, and tires, to guns, drugs, pesticides, and other chemicals, are daily productive of injury, death, or disease. Surely we should demand of their manufacturers that all reasonable steps be taken to protect us against harm where feasible and affordable curative measures will not diminish unduly the usefulness of the products, ${ }^{115}$ and in some circumstances we may fairly hold the manufacturers "strictly" to account for their failure to protect us. ${ }^{\text {116 }}$

111 "[E]very one of a car's 14,000 parts can be modified in many ways, and every modifcation will have effects that depend upon interactions with other parts." Wheeler, Costly Mistrust, supra note 2, at 27. See also O'Donnell, supra note 86, at 1060.

${ }^{112}$ This is to say nothing of the increases in weight and cost and decreases in roominess, maneuverability, and fuel efficiency that may result. See also Dawson v. Chrysler Corp., 630 F.2d 950, 962-63 (3d Cir. 1980), cert. denied, 450 U.S. 959 (1981).

${ }_{113}$ See, e.g., id.; Owens v. Allis-Chalmers Corp., 83 Mich. App. 74, 268 N.W.2d 291 (1978).

114 See generally Birnbaum, Unmasking the Test for Design Defect: From Negligence [to Warranty] to Strict Liability to Negligence, 33 VAND. L. REv. 593 (1980); Epstein, Products Liability: The Search for the Middle Ground, 56 N.C.L. REv. 643 (1978); O'Donnell, supra note 86; Wade, On Product "Design Defects" and Their Actionability, 33 VAND. L. REv. 551 (1980).

${ }^{115}$ The law of negligence liability for compensatory damages purports to promote this goal. See generally Posner, supra note 98.

116 For a variety of reasons, the principles of negligence in recent years have been 
Moreover, when a manufacturer knowingly sacrifices the public's greater safety interests to reap a profit that it knows is worth much less, punitive damages are in order. ${ }^{117}$ Yet many useful products must be placed on the market with risks of unknown type or extent, and manufacturers must be protected scrupulously against punishment for their good faith decisions to market such products, even if they contain substantial risks.

Writing early in the products liability era, Professor Thomas Cowan demonstrated that a manufacturer's choices involving necessary safety trade-offs and statistically inevitable risks always can be viewed in a sense as intentional wrongs to consumers hurt by such products, ${ }^{118}$ as safe on balance as such products may actually be. Although he did not propose that punitive damages be awarded in such cases, the inherent deliberateness (or "consciousness") of the manufacturing process is highlighted by his analysis. So too is the need for a standard of punitive damages liability fashioned to the context; only such a standard will ensure that the necessarily deliberate nature of a manufacturer's decision making will not be twisted artfully and unfairly into an appearance of conscious wrongdoing. In a courtroom many years after the fact, especially where the risks have proven to be greater than had been thought, even the most conscientious design of a complex and risky product can be made to look cold, calculating, and "callous," and as if the manufacturer deliberately had "disregarded" the risks it could foresee; of course in a sense it did, if it was properly doing its job. ${ }^{119}$

Guidance more precise than "flagrant indifference" to consumer safety, however, is necessary for both manufacturers and the tribunals that judge their conduct. In my earlier study, I offered

viewed increasingly as more appropriate than those of true strict liability for use in design and warnings cases. See authorities cited supra note 114.

117 See text at note 100 supra.

118 See Cowan, Some Policy Bases of Products Liability, 17 Stan. L. REv. 1077 (1965). See also LeBel, Intent and Recklessness as Bases of Products Liability: One Step Back, Two Steps Forward, 32 ALA. L. Rev. 31, 41 (1980).

11 Although most (but by no means all) lawyers, judges, and public policy makers may comprehend and agree with this point, one may seriously question whether the ordinary person-or juror-can or would: "A lawyer may be hardened to the unpleasant realities lurking beneath the genteel talk of 'balancing factors' but unless he is instructed to the contrary, the ordinary citizen might well believe a manufacturer has no moral authority to sacrifice the interests of the few for the many." O'Donnell, supra note 86, at 1069-70; see note 266 infra. 
several factors as guides in judging a manufacturer's behavior, ${ }^{120}$ and at least one court has found them useful in that regard. ${ }^{121}$ The factors themselves simply represent the component parts of manufacturing decisions affecting safety and include principally the degree of risk, the cost and availability of feasible measures to reduce the risk, and the nature of the manufacturer's actions in light of its awareness of the risk.

Although a manufacturer's culpability can be measured against the framework of these factors, an affirmative definition of the basis for liability should be provided to guide judge and jury. An examination of the cases that have struggled with the issue reveals that punitive damages generally are appropriate in only two types of cases-those involving behavior of a fraudulent character, where the manufacturer purposefully created the danger in an effort to trick consumers into buying the product, ${ }^{122}$ and those in which the manufacturer chose to profit from exposing consumers to a high risk of serious injury that it $\mathrm{knew}^{128}$ could easily be avoided through feasible and economical curative measures. If the facts of the case do not fit into either of these two classifications, punitive damages probably are inappropriate and usually should be stricken from the case.

Punitive damages ordinarily will be proper only in cases of extreme departure from accepted safety norms in the particular industry. ${ }^{124}$ To avoid punitive damages assessments for simply erring

120 Those factors were as follows:

(1) the existence and magnitude in the product of a danger to the public;

(2) the cost and feasibility of reducing the danger to an acceptable level;

(3) the manufacturer's awareness of the danger, of the magnitude of the danger, and of the availability of a feasible remedy;

(4) the nature and duration of, and the reasons for, the manufacturer's failure to act appropriately to discover or to reduce the danger; and

(5) the extent to which the manufacturer purposefully created the danger. Owen, supra note 7, at 1369.

${ }^{121}$ See Gryc v. Dayton-Hudson Corp., 297 N.W.2d 727 (Minn.), cert. denied, 449 U.S. 921 (1980), where the court analyzed the facts in terms of these and three additional factors: "(6) the extent to which the defendants are subject to federal safety regulation; (7) the probability that compensatory damages might be awarded against defendants in other cases; and, finally, (8) the amount of time which has passed since the actions sought to be deterred." Id. at 739.

${ }^{223}$ See generally Owen, supra note 7, at 1329-35.

${ }^{223}$ Although the standard is stated here in subjective terms, the manufacturer's knowledge should be capable of objective proof, tested by what it plainly should have known in light of objectively provable facts. Its denial of such knowledge, therefore, will be relevant but not conclusive on the point. See text and notes at notes 108-109 supra.

${ }^{234}$ See, e.g., Linscott v. Rainier Nat'l Life Ins. Co., 100 Idaho 854, 858, 606 P.2d 958, 
on design decision "close calls," the standard must be interpreted to provide a fair measure of breathing space for the manufacturer to make good faith mistakes. ${ }^{125}$

\section{B. Matters of Aggravation}

Courts in recent cases have pointed to various types of evidence as tending to establish or aggravate a manufacturer's culpability. The following discussion examines several of the more important aggravating factors that have been emphasized.

1. Prior Complaints or Lawsuits. Several decisions have relied heavily on evidence that the manufacturer had received a number of complaints or had been the target of prior lawsuits concerning a danger of the product at issue in the case. ${ }^{126}$ Such evi-

962 (1980) (bad faith refusal to honor insurance policy):

In Idaho, then, so long as the evidence shows that there has been an injury to the plaintiff from an act which is an extreme deviation from reasonable standards of conduct, and that the act was performed by the defendant with an understanding of or a disregard for its likely consequences (in the words of prior cases, with fraud, malice or oppression), it is appropriate for the trier of fact to award punitive damages.

Compare the standard for "gross and wilful negligence" as described by Judge Learned Hand in his first classic risk-benefit case, Conway v. O'Brien, 111 F.2d 611, 612 (2d Cir. 1940) ("not only must the interest which he would have had to sacrifice be less than the risk to which he subjects others, but it must so far fail to match that risk that some opprobrium or reproach attaches to him"), rev'd on other grounds, 312 U.S. 492 (1941). See also Ballenger v. Mobil Oil Corp., 488 F.2d 707, 710 (5th Cir.) ("complete lack of any care by the defendant, which if shown raises a presumption of conscious indifference . . . The exercise of even slight care defeats the presumption."), cert. denied, 416 U.S. 980 (1974). Cf. Curtis Publishing Co. v. Butts, 388 U.S. 130, 155 (1967) (requiring on a similar rationale an "extreme departure" from the journalistic norm to establish N.Y. Times malice). See text at notes 109 supra and 174 infra. See also H.R. 5214, 97th Cong., 1st Sess. $\S 11(b)$ (1981) (proposed products liability legislation requiring "a flagrant indifference to consumer safety" and "an extreme departure from accepted practice" to establish punitive damages liability).

${ }^{125}$ For acknowledgements of the frequent need for design engineers to make close calls, see Henderson, Process Defense, supra note 50, at 384; Twerski, Shifting Perspectives, supra note 50, at 352. If punitive damages begin to be awarded in close-call cases, the entire question of their insurability will have to be rethought, for the policy considerations change substantially. See generally Owen, supra note 7, at 1308-13.

${ }^{126}$ See, e.g., Gillham v. Admiral Corp., 523 F.2d 102, 106 (6th Cir. 1975) (at least 91 fires in color television sets reported to manufacturer), cert. denied, 424 U.S. 913 (1976); Cantrell v. Amarillo Hardware Co., 226 Kan. 681, 683-84, 602 P.2d 1326, 1331 (1979) (at least five similar stepladder collapses); Gryc v. Dayton-Hudson Corp., 297 N.W.2d 727, 740 (Minn.) (six lawsuits over seven years against manufacturer of untreated cotton flannelette used in garments), cert. denied, 449 U.S. 921 (1980); Rinker v. Ford Motor Co., 567 S.W.2d 655,667 (Mo. Ct. App. 1978) (29 reports to manufacturer over four years of incidents involving fast idle cams); see also Drayton v. Jiffee Chem. Corp., 591 F.2d 352, 374 (6th Cir. 1978) (Keith, J., concurring in part and dissenting in part) ("defendant's callous argument that 'only' 59 other Liquid-plumr [caustic drain cleaner] injuries were reported to the defendant 
dence is important, for it tends to prove the existence of a hazard, its seriousness, and the manufacturer's probable knowledge of its existence. Conversely, the absence or small number of prior complaints or lawsuits is of course compelling proof to show good faith. ${ }^{127}$

The bare fact of a large number of product failures, however, falls far short of establishing the manufacturer's flagrant culpability in selling the product. For punitive damages to be appropriate, a further showing must be made that plainly available and economical preventive measures were ignored by the manufacturer for the purpose of saving corporate funds. ${ }^{128}$ Thus, although one tire blowout or steering failure may look like any other to most consumers (and jurors), many such failures often can be traced to causes for which the manufacturer is not responsible. ${ }^{129} \mathrm{~A}$ tire may fail from abuse or wear as well as from a defect; ${ }^{130}$ a steering failure may be traced to a mechanic's error in repair. ${ }^{131}$ Moreover, even failures properly attributable to the product itself may derive

is further proof of the need for punitive damages"); Forrest City Mach. Works, Inc. v. Aderhold, 616 S.W.2d 720, 727 (Ark. 1981) (Hickman, J., concurring in part and dissenting in part) (at least two other lawsuits against manufacturer of grain buggy with unshielded power takeoff shaft). See generally United School Dist. No. 490 v. Celotex Corp., 629 P.2d 196, 208-09 (Kan. Ct. App. 1981).

${ }_{127}$ See text and note at note 165 infra.

128 Of course, cost-savings motives in themselves must not be viewed as wrong, for manufacturers must remain competitive in cost and pricing to survive and to continue making products. Cf. Maxey v. Freightliner Corp., 450 F. Supp. 955, 962 (N.D. Tex. 1978) (asserting there is a potential divergence of interests between claimants seeking punitive damages and future consumers that increases with each award of punitive damages), aff'd, 623 F.2d 395 (5th Cir.), rehearing en banc granted, 634 F.2d 1008 (5th Cir. 1980). The court argued that "[p]resent tort law accepts the idea that manufacturers ought to be checked by deterrent based remedies. Yet we ought not in our quest for public safety lose sight of the obvious-with no products, there are no consumers." Id. (emphasis in original).

120 See generally W. KeETON, supra note 49, at 825-36.

${ }^{130}$ Courts often have refused to infer even liability for compensatory damages from the occurrence of an accident involving a product. In addition to the accident, the plaintiff must show the existence of a defect in the product and its causal relation to his injury. See, e.g., Shramek v. General Motors Corp., 69 Ill. App. 2d 72, 78, 216 N.E.2d 244, 247 (1966):

The mere fact of a tire blowout does not demonstrate the manufacturer's negligence, nor tend to establish that the tire was defective. Blowouts can be attributed to myriad causes, including not only the care with which the tires are maintained, but the conditions of the roads over which they are driven and the happenstance striking of damaging objects.

See also Sears, Roebuck \& Co. v. Haven Hills Farm, Inc., 395 So. 2d 991, 995, 996 (Ala. 1981).

${ }^{131}$ Cf. Scanlon v. General Motors Corp., 65 N.J. 582, 599-600, 326 A.2d 673, 682 (1974) (plaintiff's failure either to prove that an accident was caused by an original defect in his car or to negate other obvious possibilities required directed verdict for defendant). 
from a variety of causes, some going to manufacturing mistakes and others to differing problems in design. Even a large number of apparently similar product failures, therefore, does not mean that the product line contains a single "defect," much less one that is subject to feasible cure. ${ }^{132}$

The relative number of the accidents also must be kept in mind, even if they derive from identical problems in the product itself. That perhaps some fifty persons, among the occupants of several million Pintos, may have died in fire crashes over the last decade is a tragic fact indeed, ${ }^{133}$ yet some fifty thousand people die - and many more are injured - in traffic accidents in this nation every year. ${ }^{134}$ Principles of crashworthiness demand that automobile manufacturers take all reasonable steps to reduce all known and foreseeable risks as much as practicable, ${ }^{135}$ and a manufacturer should be punished for flagrantly refusing to do so. ${ }^{138}$ Yet the unhappy fact remains that feasible technology simply does not exist to reduce many such collision risks, and our society has opted more or less to keep the automobile at approximately its present balance of safety risks and related trade-offs-price, size, style, fuel effciency, and maneuverability. The collective decision has been made that we cannot yet afford to be safety absolutists. ${ }^{137}$ Thus the tragic fact that dozens of people have died in Pinto fires over the last decade should not mask the fact that thousands have died in fire crashes in other subcompacts and larger vehicles over the same period, ${ }^{138}$ reflecting the statistical inevitability of such acci-

132 The determination of the "similarity" of prior claims or accidents in these cases is thus not as easy as it may first appear. The court in a recent gun explosion case remarked as follows:

The purpose of the admission of prior occurrences to establish punitive damages in products liability cases is to show that the manufacturer had or should have had knowledge of harm inflicted on consumers by its product and with flagrant indifference to public safety failed to warn consumers of or remedy the defect. . . . Guns are inherently dangerous instrumentalities. The mere fact that other guns had exploded does not, therefore, in and of itself support the existence of a defect.

Moore v. Remington Arms Co., 100 Ill. App. 3d 1102, 1112, 427 N.E.2d 608, 615 (1981) (company knew of 67 prior explosions of same model shotgun).

133 See TIMe, Mar. 24, 1980, at 24.

134 The preliminary estimates for 1979 are as follows: deaths-51,083; disabling injury accidents-450,000; injuries-3,830,000; police-reported traffic accidents-7,200,000. U.S. Dep't of Transportation, Motor Vehicle Sapety-1979, at 2, 6 (1981).

${ }^{135}$ See generally W. KEETON, supra note 49, at 412-31.

${ }_{138}$ See, e.g., Dorsey v. Honda Motor Co., 655 F.2d 650, 658 (5th Cir. 1981); Leichtamer

v. American Motors Corp., 424 N.E.2d 568, 580 (Ohio 1981).

${ }_{137}$ See, e.g., Johnson, The Perils of Risk Avoidance, REG., May/June 1980, at 15.

138 It appears that some 500-1000 persons die from traffic accident fires in this nation 
dents in general under prevailing levels of technology, wealth, and social preference. ${ }^{139}$

It is also important to view the number of complaints and lawsuits concerning a product in the context of the total number of products sold and in use, the frequency of the product's use, and the particular product's inherent dangers. Thus, it must be expected that virtually all manufacturers of mass-produced goods that are inherently dangerous-automobiles, tires, drugs, chemicals, or firearms-will be the targets of many complaints and lawsuits every year. ${ }^{140}$ Reports of possible defects must of course be investigated to see if there really is a problem with the product and, if so, whether feasible curative measures can be found.141 For the many reasons discussed above, however, the fact that a manufacturer is shown to have received a number of complaints or to have been the target of previous lawsuits can only be the first step in proving a punitive damages claim.

2. Violation of Safety Standards. If a manufacturer knowingly chooses to violate the safety practices of its industry, it will bear a heavy burden to demonstrate the good faith of that decision. For example, in Wussow v. Commercial Mechanisms, Inc. ${ }^{142}$ the fourteen-year-old plaintiff was injured severely when struck in the head by the arm of an automatic baseball pitching machine manufactured by the defendant. ${ }^{143}$ The machine was unplugged at

each year. A widely publicized 1973 Department of Transportation estimate of 2000-3500 annual fatalities appears to have been substantially in error. See P. Coolrgy, Frre IN Motor Vehicle Accidents 59-60 (Highway Safety Research Inst., U. Mich., Apr. 1974) (actual number estimated between 450-650); Flora \& O'Day, An Estimate of the Effect of FMVSS 301-Fuel System Integrity, 13 Accident ANALYsis \& PREVkntion 117 (1981) (1976-814 auto fire deaths; 1977-982). See generally Investigative Report, MOTOR TRRND, Mar. 1974, at 84-86.

Statistics from the mid-1970's show that the Pinto fire-fatality rate was within the norm for subcompacts. See Defendant's Exhibit EE, State v. Ford Motor Co., No. 5324 (Super Ct. Elkhart Cty., Ind., Sept. 13, 1978) (setting forth National Highway Transportation Safety Administration's Fatal Accident Reporting System data for post-1970 cars in fatal fire accidents, per million cars in operation, for 1975 \& 1976: all vehicles- 6.8; all compacts- 7.3; Pinto- 7.0; VW- 9.3; Vega- 7.0; Datsun- 9.7; Toyota- 4.9; Gremlin9.8; Dodge Colt- 5.3; Opel- 8.8; Honda- 11.1).

${ }^{139}$ Cf. Landes \& Posner, supra note 76, at 148-49 (commenting on inappropriateness of finding "intent" where there is merely statistical inevitability of accidental injury).

140 See W. KEETON, supra note 49, at 1-16. Ford Motor Company, which has hundreds of products liability lawsuits filed against it each year, see note 258 infra, is probably typical in this respect, at least of automobile manufacturers.

141 See text and note at note 162 infra.

14297 Wis. 2d 136, 293 N.W.2d 897 (1980).

14 Id. at $139-40,293$ N.W.2d at 899. 
the time of the accident, but the arm had been left in an "energized" (cocked) position. Affirming the jury's award of punitive damages, ${ }^{144}$ the Wisconsin Supreme Court pointed in part to the defendant's failure to attach safety guards it knew were used on its competitors' machines. ${ }^{148}$ Violations of government safety statutes or regulations also undercut claims of good faith. ${ }^{148}$ In some instances, however, such regulations may be unnecessarily stringent, and the common practice consequently may be to ignore them. ${ }^{147}$ Yet, the burden clearly to demonstrate a standard's inappropriateness should fall upon the manufacturer.

3. Ready Availability of Inexpensive Remedies. An important aggravating factor in some cases is the manufacturer's awareness of an easy solution to the problem plainly demanded by its simplicity and economy. ${ }^{148}$ The Grimshaw court thus was impressed that there were a variety of "inexpensive fixes," each costing only several dollars, that supposedly could have solved the Pinto's gas tank problem. ${ }^{14 \theta}$

144 The punitive damages awarded totalled $\$ 70,000$, an amount described by the court as "modest indeed." Id. at 156, 293 N.W.2d at 907.

${ }^{145}$ Id. at 153-54, 293 N.W.2d at 906. See also Dorsey v. Honda Motor Co., 655 F.2d 650, 655-56 (5th Cir. 1981); Gillham v. Admiral Corp., 523 F.2d 102, 106 (6th Cir. 1975), cert. denied, 424 U.S. 913 (1976); Forrest City Mach. Works, Inc. v. Aderhold, 616 S.W.2d 720, 727 (Ark. 1981) (Hickman, J., concurring in part and dissenting in part).

${ }_{146}$ See generally Owen, supra note 7, at 1335-39.

167 See, e.g., Barth v. B.F. Goodrich Tire Co., 265 Cal. App. 2d 228, 238, 71 Cal Rptr. 306, 311 (1968); cf. American Motors Corp. v. Ellis, 403 So. 2d 459, 469 (Fla. Dist. Ct. App. 1981) (Cowart, J., concurring in part and dissenting in part) (describing engineers' reluctant decision to comply with government standards which they regarded as inappropriate for "real world conditions").

${ }_{148}$ See, e.g., Gillham v. Admiral Corp., 523 F.2d 102, 107 n.3 (6th Cir. 1975) (change in high voltage transformer materials at cost of $\$ 0.60-1.20$ per color television unit), cert. denied, 424 U.S. 913 (1976); Wussow v. Commercial Mechanisms, Inc., 97 Wis. 2d 136, 155, 293 N.W.2d 897, 906-07 (1980) (addition of safety guard to automatic pitching machine).

148 Design changes that would have enhanced the integrity of the fuel tank system at relatively little cost per car included the following: Longitudinal side members and cross members at $\$ 2.40$ and $\$ 1.80$, respectively; a single shock absorbent "flak suit" to protect the tank at \$4; a tank within a tank and placement of the tank over the axle at $\$ 5.08$ to $\$ 5.79$; a nylon bladder within the tank at $\$ 5.25$ to $\$ 8$; placement of the tank over the axle surrounded with a protective barrier at a cost of $\$ 9.95$ per car; substitution of a rear axle with a smooth differential housing at a cost of $\$ 2.10$; imposition of a protective shield between the differential housing and the tank at $\$ 2.35$; improvement and reenforcement of the bumper at $\$ 2.60$; addition of eight inches of crush space [at] a cost of $\$ 6.40$. Equipping the car with a reinforced rear structure, smooth axle, improved bumper and additional crush space at a total cost of $\$ 15.30$ would have made the fuel tank safe in a 34 to 38-mile-per-hour rear end collision by a vehicle the size of a Ford Galaxie. If, in addition to the foregoing, a bladder or tank within a tank were used or if the tank were protected with a shield, it would have been safe in a 40 to 45 - 
A court must be wary of three pitfalls, however. First, the inexpensive remedy factor is only one among the several that must be present in combination to establish flagrant misconduct. ${ }^{160}$ Thus, without proof of a serious hazard clearly calling for attention, evidence of the availability of safer procedures that are simple and inexpensive simply has no force. ${ }^{151}$ Second, any design alternative advanced by the plaintiff must of course be likely to have prevented his harm, or he will fail on the causation aspect of his case. ${ }^{152}$ Third, courts and juries must be certain that any "cheap fixes" proposed by plaintiff's experts were in fact feasible, available, and economical in the industry at the time. In many industries, most qualified design experts are employed by the manufacturers; ${ }^{163}$ the credentials and alternative design theories of many plaintiffs' experts should therefore be examined with special scrutiny. ${ }^{154}$

One must be somewhat skeptical of the Grimshaw court's heavy reliance on an array of purported "cheap fixes," some of which may not have been feasible at all. For example, the court appeared to be impressed with the concept of adding a rubber or nylon bladder to the inside of the gas tank. ${ }^{155}$ Yet such bladders apparently are still not generally used in commercially produced cars; one thus must wonder whether they are feasible even today'ss

mile-per-hour rear impact. If the tank had been located over the rear axle, it would have been safe in a rear impact at 50 miles per hour or more.

$119 \mathrm{Cal}$. App. 3d at 775-76, $174 \mathrm{Cal}$. Rptr. at 361 (reciting the evidence in the light most favorable to the judgment below).

180 See note 120 supra.

151 See American Laundry Mach. Indus. v. Horan, 45 Md. App. 97, 117, 412 A.2d 407, 420 (1980):

The only evidence offered in support of [plaintiff's] entitlement to punitive damages in this case was . . . failure to use the patented cut-off device and failure to warn of the danger....

Wanton and reckless conduct . . . requires, in this context, direct evidence of substantial knowledge on the part of the manufacturer that the product is, or is likely to become, dangerous, and a gross indifference to the danger. Such evidence simply does not exist in this case.

See also Newding v. Kroger Co., 554 S.W.2d 15, 18 (Tex. Civ. App. 1977).

132 See text and note at note 197 infra.

183 See, e.g., statistics for mechanical engineers cited in Burgau op Labor Statistics, Occupational OUTLOOK HaNdBooK 351 (1978-79 ed.).

IB6 See, e.g., Singleton v. International Harvester Co., No. 80-1445 (4th Cir. May 13, 1981). See generally W. Kegron, supra note 49, at 58, 882; O'Donnell, Design Litigation and the State of the Art: Terminology, Practice and Reform, 11 AKron L. REv. 627, 646-61 (1978).

155119 Cal. App. 3d at 775, 776, 174 Cal. Rptr. at 360, 361.

138 "Moreover, fuel bladders, as appealing as their usage may be given their apparent 
or, if they are, whether they would do much good. Similar problems of feasibility are raised by the court's reliance on testimony that an over-the-axle location of the fuel tank would have been a preferable design, because such a tank apparently cannot be built into a small hatchback car such as the model of Pinto involved in Grimshaw. ${ }^{\mathbf{1 5 7}}$

Apart from problems with the practicality of a proposed remedial design in light of available technology and the environment of the product's use, the monetary cost of such alternatives must also be given careful thought. In a complex product such as a car, there are always hundreds of design changes that can be made to enhance the safety of the vehicle in a particular type of a crash situation, ranging in cost per unit from pennies to hundreds of dollars. ${ }^{158}$ Although the cost of any one change may be small in isolation, all we can fairly ask of management and its engineers in the punitive damages context is that safety considerations not be deliberately excluded or shunted far to the rear in deciding on the total design mix involved. Each separate design choice is of course only a small sub-decision in the overall safety-cost-utility mix that must be tailored to the special needs and limitations of each different type of product. ${ }^{159}$

Moreover, the frailties of the engineering art are such that

simplicity of manufacture, have not been used in tanks in any of the millions of automobiles now on the road." Maxey v. Freightliner Corp., 450 F. Supp. 955, 963-64 (N.D. Tex. 1978), aff'd, 623 F.2d 395 (5th Cir.), rehearing en banc granted, 634 F.2d 1008 (5th Cir. 1980).

General Motors did install flexible, rubber fuel bladders in the Corvette from 1975-77 but switched to a molded plastic liner in 1978. Telephone interview with Frank W. Allen, Asst. Gen. Counsel, Gen. Motors Corp. (Feb. 1, 1982). See also Letter from John P. Eppel, Asst. Gen. Counsel, Ford Motor Co., to David G. Owen, app. (October 22, 1981) (noting problems of bladder durability and serviceability) (on file with The University of Chicago Law Review) [hereinafter cited as Eppel Letter]; interview with John P. Eppel in Dearborn, Mich. (July 9, 1981).

${ }^{167}$ Reply Brief and Cross-Respondent's Brief of Ford Motor Co. at 4, Grimshaw.

${ }^{158}$ Consider the remarks of Judge Cowart, concurring in part and dissenting in part in American Motors Corp. v. Ellis, 403 So. 2d 459, 469 (Fla. Dist. Ct. App. 1981):

The majority states that failure to build to a safer design "in order to maximize profits" should support an award of punitive damages here. Any product, especially an automobile, can always be redesigned to increase user safety. However, increases in safety necessitate increases in cost; a perfectly safe automobile would be unaffordable. Therefore, in order to retain a salable product, the manufacturer is always forced to reduce the safety of the design by some amount from the ideal. Therefore, for any given product, the manufacturer will always have failed to make the product safer because of considerations of profit. Such practical economic considerations are not at all wrongful, much less malicious.

158 See text and note at note 111 supra. 
some good-faith errors sometimes will be made, and injuries sometimes will result. In a products liability case seeking compensation for such injuries, a principal inquiry will be to isolate the design choice that could have prevented the injury and to focus on its cost. Although the cost of such a single "fix" will often seem quite low in absolute terms, we must not lose sight of the facts that at the time of design, the fix was merely one of a great many options considered for inclusion in the total design mix, and that human injury from any one was at most at that time only a foreseeable risk. To pin a bad-faith label on whichever one of these decisions years later proves to have been wrong thus should require much more than proof that the cost of the particular fix was "small."

4. Corporate Policies and Procedures. Our society has now reached the stage where we demand that manufacturers of inherently dangerous products institutionalize procedures for minimizing and correcting hazards in their products. ${ }^{160} \mathrm{~A}$ total absence or palpable inadequacy of regular safety procedures demonstrates an indifference to consumer safety. ${ }^{161}$ The expenditure of only paltry sums on research into flame retardants by a manufacturer of highly flammable cotton flannelette for use in children's nightwear is evidence of this type. ${ }^{182}$ Insufficient crash-testing of a vehicle also has been cited in this regard, ${ }^{183}$ and one recent case has pointed to the manufacturer's failure to have in place a "formal safety review committee" that probably would have detected and eliminated the hazard. ${ }^{164}$

100 Reasonable attention to safety normally includes, at a minimum, premarketing engineering studies and prototype testing, assembly line quality controls, consideration of appropriate warnings and instructions, and field performance monitoring and response.

161 Evidence of this type of "passive" indifference to consumer safety was the principal basis of the dissenting opinion in Maxey v. Freightliner Corp., 623 F.2d 395, 404 (5th Cir.) (Johnson, J., dissenting) (citing defendant's failure to crash-test its truck tractors and to stay abreast of accident statistics and engineering developments), rehearing en banc granted, 634 F.2d 1008 (5th Cir. 1980). See also text and note at note 74 supra.

${ }^{182}$ Gryc v. Dayton-Hudson Corp., 297 N.W.2d 727, 740 (Minn.), cert. denied, 449 U.S. 921 (1980). The court pointed to the defendant's "minimal" efforts in its "surveillance of developments in the flame-retardant field," noted that it had "kept no records on its research and development" on flammability prevention, and remarked that from 1967 to 1969, the company had spent but $\$ 140,000$ on this type of research out of its total research and development budget of $\$ 1.8$ million. Id.

${ }^{163}$ Leichtamer v. American Motors Corp., 424 N.E.2d 568, 580 (Ohio 1981). A manufacturer must not be expected, however, to conduct crash experiments to test the durability of its vehicles in all the myriad contexts in which crashes can occur. Such tests are expensive, typically costing roughly $\$ 10,000$ plus the cost of the vehicle. See Eppel Letter, supra note 156 , at 2.

${ }^{184}$ Wussow v. Commercial Mechanisms, Inc., 97 Wis. 2d 136, 153, 293 N.E.2d 897, 906 


\section{Matters of Defense and Mitigation}

Just as the courts have indicated circumstances of aggravation tending to demonstrate flagrant misconduct, so also have they pointed to mitigating circumstances cutting against the award of punitive damages. As a general principle, proof of an absence or converse of the aggravating factors discussed above tends to prove good faith. For example, the absence or low number of prior complaints tends to support a manufacturer's claim of ignorance of a problem in need of attention, ${ }^{185}$ and the routine use of bona fide safety procedures ordinarily should protect the manufacturer against punitive damages when the procedures sometimes fail. And if the defendant can show that its management is new and has purged the enterprise of the prior misconduct, the punitive damages case is weakened substantially. ${ }^{168}$

Two broad contexts of mitigation deserve special attention: those going to the defectiveness vel non of the product and those going to the causal circumstances of the accident apart from the product itself.

1. Product Defectiveness. a. In general. There can be no liability, of course, either for compensatory or for punitive damages if the product is not legally defective in the first place. However dangerous a product may be, and however many injuries may be associated with it, the manufacturer cannot be held liable if the product was not in fact "defective." This is what courts mean when they note that manufacturers are not held to be insurers of product safety or insurers against product accidents. ${ }^{187}$ To most courts, this means that there is no liability for legal defectiveness unless (1) there was an error in the manufacture of the product, (2) the

\section{(1980).}

18s See, e.g., Johnson v. Husky Indus., Inc., 536 F.2d 645, 651 (6th Cir. 1976) (three prior claims concerning risks from inhaling carbon monoxide fumes from charcoal briquets burned indoors); Thomas v. American Cystoscope Makers, Inc., 414 F. Supp. 255, 266 (E.D. $\mathrm{Pa}$. 1976) (no prior reports of electrical burns to cornea of eye from electrical arcing on eyepiece of surgical telescopic instrument); Turney v. Ford Motor Co., 94 Ill. App. 3d 678, 686, 418 N.E.2d 1079, 1086 (1981) (six tractor roll-overs in ten years); American Laundry Mach. Indus. v. Horan, 45 Md. App. 97, 117, 412 A.2d 407, 420 (1980) (no complaints of extractors disintegrating in 18 years).

${ }_{168}$ See Drayton v. Jiffee Chem. Corp., 591 F.2d 352, 366 (6th Cir. 1978), aff'g 395 F. Supp. 1081, 1098 (N.D. Ohio 1975). But cf. Wussow v. Commercial Mechanisms, Inc., 97 Wis. $2 d$ 136, 154-56, 293 N.W.2d 897, 906-07 (1980) (new owner retained old management and was aware of safety hazards).

187 See, e.g., Turney v. Ford Motor Co., 94 Ill. App. 3d 678, 687, 418 N.E.2d 1079, 1086 (1981) (quoting Hunt v. Blasius, 74 Ill. 2d 203, 211-12, 384 N.E.2d 368, 372 (1978)). 
product's safety was affirmatively misrepresented, (3) the injury results from a hidden or otherwise unexpected danger, or (4) the manufacturer failed to apply identifiable preventive measures that were feasible and cost-effective. In short, there must have been something "wrong" with the product that caused the plaintiff"s injuries before there can be liability for that harm. ${ }^{188}$

Although defects (1) and (2) are typically apparent to the manufacturer, and thus, their deliberate creation often flagrantly improper, the design and warnings "defect" notions of (3) and (4) are surrounded by shrouds of mist. The mist exists, of course, only in the middle of the spectrum, and cases do arise at either extreme, where the product is clearly defective or not. Yet for the great number of cases in the middle, the legal "tests" of liability for such defects are by their nature so vague that they are often effectively meaningless as guides for design engineers attempting to comply with the law. ${ }^{169}$ There is therefore a vast defect "no man's land" where a manufacturer has no idea whether it is on the right or wrong side of the law. One indeed may ask whether "law" itself exists in such terrain, or whether "lawless" is the better word to describe the prevailing "rule" of random guilt. ${ }^{170}$ The very notion of how much design safety is enough, and to a lesser extent how much safety information is enough, involves a morass of conceptual, political, and practical issues on which juries, courts, commentators, and legislatures strongly disagree. ${ }^{171}$ But because al-

ies See generally RESTATEMENT, supra note 35 , $\$ 402(\mathrm{~A})(1)$ \& comments $\mathrm{g} \& \mathrm{~h}$.

180 See generally Henderson, Manufacturers' Liability for Defective Product Design: A Proposed Statutory Reform, 56 N.C.L. REv. 625 (1978); O'Donnell, supra note 86.

${ }^{170}$ Cf. Rabin, Dealing with Disasters: Some Thoughts on the Adequacy of the Legal System, 30 Stan. L. REv. 281, 297 (1978), commenting on the task of the plaintiffs' lawyer in the 1972 Buffalo Creek flood disaster case:

Unfortunately, the distinction between recklessness and negligence relates to no clear behavioral standards in the real world. Baldly stated, Stern's task was to amass sufficient evidence of negligence to make the defendants look "awfully negligent," and his success at trial almost certainly would have turned on the jury's emotional reaction to the victims' suffering.

It is truly striking how we have devised a system that is not far removed from a lottery for deciding such grave matters-with the draw determined by not only the predilections of the presiding judge, but the emotions of the jury sitting in the case.

${ }^{171}$ Where the courts themselves are in disagreement on whether a particular type of product danger should give rise to liability even for compensatory damages, the imposition of punitive damages upon a manufacturer on the basis of that danger would seem particularly inappropriate in most cases. For example, for machines where certain types of safety features are often offered as optional features, a manufacturer's failure to incorporate the feature as standard equipment generally should preclude an award of punitive damages. $C f$. Turney v. Ford Motor Co., 94 Ill. App. 3d 678, 683, 418 N.E.2d 1079, 1083 (1981) (seat belt 
most all agree that perfect safety cannot yet be our legal goal, design engineers simply must continue to make the best judgments that they can on the balance of trade-offs between safety, utility, and cost-the incommensurable components of "defectiveness."

For defect types (3) and (4), there probably cannot in the nature of things be a bright line separating good products from bad to guide the engineer or the judicial forum reviewing his work years hence. In the defect "no man's land," punitive damages simply have no place. ${ }^{172}$ If such decisions fall within any reasonable distance of the "defect line," even if in hindsight proven wrong, fairness requires that they ordinarily be judged to have been made in good faith. Stated in another way, even if the product is finally found "defective," the case for punitive damages almost always will be quite weak if a plausible case for nondefectiveness was made the other way. Such damages usually will not be appropriate unless the product was very defective, and plainly so, at the time it was sold. ${ }^{173}$ A plaintiff usually should be entitled to a directed verdict on defectiveness, or close thereto, before the punitive damages issue is properly before the jury at all. ${ }^{174}$

b. Obvious or known dangers. If a danger is obvious or known to the user, there of course is no duty to warn. ${ }^{175}$ In design cases, however, the "patent danger" rule has now been repudiated for the most part as a basis for directed verdicts against plaintiffs, ${ }^{176}$ and there usually is a duty to design such dangers out of the product if it is feasible and economical to do so. ${ }^{177}$ Yet the better-reasoned decisions generally retain obviousness or knowledge of the hazard within the design defectiveness equation as one of several factors to be considered. ${ }^{178}$

and roll-bar package supplied as optional equipment).

${ }^{173}$ Cf. Landes \& Posner, supra note 76, at 136 (noting inappropriateness of punitive damages in situations where it is difficult to distinguish good acts from bad).

${ }^{173} \mathrm{Cf}$. id. at 137 (case 4a) (noting inappropriateness of punitive damages for unreasona-

ble but honest mistakes). See also text and note at note 124 supra.

174 See text at notes 107-109 supra.

${ }^{175}$ See, e.g., Forest City Mach. Works, Inc. v. Aderhold, 616 S.W.2d 720, 723 (Ark. 1981). A few ill-considered opinions are to the contrary. See generally W. KEETon, supra note 49 , at $337 \mathrm{n} .8$.

${ }_{178}$ See W. KeETon, supra note 49 , at 399-408.

177 See, e.g., Sturm, Ruger \& Co. v. Day, 594 P.2d 38, $43-44$ (Alaska 1979), on rehearing, 615 P.2d 621 (1980). But cf. McIntyre v. Everest \& Jẻnnings, Inc., 575 F.2d 155, 159 (8th Cir.) (no duty to warn paraplegic plaintiff of obvious dangers of tipping movable commode), cert. denied, 439 U.S. 864 (1978).

${ }_{178}$ See, e.g., Micallef v. Miehle Co., 39 N.Y.2d 376, 387, 348 N.E.2d 571, 578, 384 N.Y.S.2d 115, 122 (1976). 
In the context of a claim for punitive damages, the principles generally track along a similar path, yet the obviousness of the danger should offer somewhat more protection to the manufacturer. Although the obviousness of a danger should not shield him in every type of case, it often reduces the chance of injury and shifts to the consumer the final choice of whether and how to engage the risk. Because the consumer can control his fate, the manufacturer of "defective" products of this type ordinarily is not nearly so much to blame as when the existence or nature of the risk is concealed from view. ${ }^{179}$

For example, in Sturm, Ruger \& Co. v. Day, ${ }^{180}$ where the plaintiff shot himself in the leg when he dropped a loaded gun, he surely knew of the obvious risk of discharge in such an event. Moreover, the manufacturer had given at least some warnings and instructions on the specific risk involved-the possibility of accidental discharge when the hammer was placed in a partially loaded position. ${ }^{181}$ Although the Alaska Supreme Court was not convinced that the manufacturer should therefore be relieved of the jury's punitive damages verdict altogether, it did reduce the amount awarded many fold. ${ }^{182}$

Cases in which a substantial danger is unknown or uncomprehended by the consumer, who to that extent has no control over his safety welfare, are to be contrasted. Gryc v. Dayton-Hudson Corp., ${ }^{183}$ where the young girl's burns resulted from the "racing flammability"184 of her nightgown's fabric, is one such case; so too

170 The autonomy of individuals in obvious danger cases is generally not at stake, while the group interest in cost-efficiency may be promoted in such cases by a no-liability rule. See the discussion and authorities cited supra note 97.

180 594 P.2d 38 (Alaska 1979), on rehearing, 615 P.2d 621 (1980).

${ }^{181}$ In particular, the risk occurred when the hammer was placed on the loading notch. Id. at $41,43$.

182 The permissible award was reduced on the first appeal from the $\$ 2.9$ million verdict to $\$ 250,000,594$ P.2d at $48-49$, yet was increased to $\$ 500,000$ on the second appeal, 615 P.2d at 624. See also McIntyre v. Everest \& Jennings, Inc., 575 F.2d 155, 159-60 (8th Cir.) (risk to paraplegic of tipping over commode chair from leaning forward to pick up toothbrush), cert. denied, 439 U.S. 864 (1978); Forrest City Mach. Works, Inc. v. Aderhold, 616 S.W.2d 720,724 (Ark. 1981) (risk of injury if pants leg caught in unguarded power take-off shaft on tractor). One also might think that the general collision risks to occupants of a subcompact Honda automobile similarly would be so apparent as to preclude a finding of "malice" in design. A district court's holding to this effect was reversed on appeal, however, and the punitive damages verdict for $\$ 5$ million reinstated, in Dorsey v. Honda Motor Co., 655 F.2d 650 (5th Cir. 1981).

${ }^{183} 297$ N.W.2d 727 (Minn.), cert. denied, 449 U.S. 921 (1980).

184 Id. at 733. 
is the Wussow ${ }^{185}$ case, where the boy could have had no idea that bumping the arm of the unplugged pitching machine would cause the arm to strike his head with explosive force. ${ }^{188}$ Grimshaw may also involve this factor to a large extent, for the risk of being burned to death while trapped inside a car is an insidious hazard not to be expected from a low-impact collision from the rear. A manufacturer's deliberate refusal to apply simple, curative measures to resolve such hidden dangers-and its refusal to warn of them-involves a moral failure of a considerably greater dimension than a failure to repair a danger that is open for all to see. ${ }^{187}$

c. Compliance with industry custom. It is well established that compliance with custom is relevant but not conclusive evidence of due care in an action based on negligence. ${ }^{188}$ Although compliance with custom is less relevant to the defect question in strict liability, ${ }^{188}$ it properly has been accorded substantial weight in the punitive damages context. In Maxey v. Freightliner Corp., 180 the decisive factor in the trial court's decision to set aside the jury's $\$ 10$ million punitive damages assessment was the fact that the design of the fuel system on the defendant's truck tractor followed the prevailing industry design in all material respects. ${ }^{101}$

In a typical case, compliance with a universal industry custom should be held conclusively to establish good faith against a punitive damages claim. Rarely will an entire industry act with flagrant impropriety against the health and safety of the consuming public,

${ }^{188}$ Wussow v. Commercial Mechanisms, Inc., 97 Wis. 2d 136, 293 N.W.2d 897 (1980).

${ }^{186} I d$. at 140,293 N.W.2d at 899.

18r The deliberate refusal to warn persons known to need vital safety information has an appearance of fraud by nondisclosure. See RESTATEMENT, supra note 35 , $5551(2)$ (e). As has been noted, see text and note at note 122 supra, punitive damages are especially appropriate in cases involving fraud. "Typical" warnings cases, however, rarely appear to involve flagrant misbehavior. The reason for this is a difficult question, but it probably reflects the growing skepticism of the efficacy of warnings.

${ }^{288}$ See W. KeEton, supra note 49 , at 59 n.4.

${ }^{189}$ See Sturm, Ruger \& Co. v. Day, 594 P.2d 38, 45 (Alaska 1979), on rehearing, 615 P.2d 621 (1980).

190450 F. Supp. 955 (N.D. Tex. 1978), aff'd, 623 F.2d 395 (5th Cir.), rehearing en banc granted, 634 F.2d 1008 (5th Cir. 1980).

181 Two of three judges on appeal agreed. 623 F.2d at 399. The dissenting judge argued that "[i]ndustry custom will frequently be an excuse for doing nothing," observing that "[i]ndustry custom may well deter safe product design. It can embody and preserve conscious disregard for the welfare of others." Id. at 405 (Johnson, J., dissenting) (footnote omitted). See also Drayton v. Jiffee Chem. Corp., 591 F.2d 352, 374 (6th Cir. 1978) (Keith, J., concurring in part and dissenting in part) ("If an entire industry monolithically markets a dangerous product instead of competing to make a safer product, the deterrent effect of punitive damages is vitally needed."). 
and running with the pack in general should shield a manufacturer from later punishment for conforming to the norm. There may be rare cases, however, as the Gryc flammability case may have been, ${ }^{192}$ where an entire industry failed in a major way to respond with even minimal responsibility to a serious consumer risk. For this reason, compliance with an industry custom probably should not be an absolute defense to a punitive damages claim in every case.

d. Compliance with statute or regulation. The principles pertaining to the effect of compliance with a statutory or regulatory safety standard are quite similar to those concerning custom. Such standards usually establish only a minimum floor, however, below which conduct is criminal; the acceptable safety level thus may be considerably higher. ${ }^{193}$ In such cases, therefore, a manufacturer should not be protected automatically from punitive damages by establishing its compliance with government safety provisions. This is what the Gryc court held, ruling that the fabric manufacturer could not defend itself conclusively from punitive damages by proving its compliance with a government regulation widely known to be far too lax to have any real protective effect. ${ }^{194}$

Many government standards, however, are adopted with studied care, and some are placed close to the line of feasible technology; ${ }^{198}$ others are set in a wide gray area where the difficulties of

102 See text and notes at notes 162, 183-184 supra. Apparently no American manufacturers were flame-retarding cotton flannelette at the time, although manufacturers in England had been flame-retarding similar sleepwear as required by law for a decade. 297 N.W.2d at 731.

${ }^{193}$ This is the reason commonly given for why liability for compensatory damages should not be barred conclusively on proof of compliance with a governmental safety standard. See generally W. KEETON, supra note 49, at 296-304, 365-73.

104 297 N.W.2d at 733-35. Commentators have noted:

The Flammable Fabrics Act, originally enacted in 1953, and amended in 1967, has been the subject of substantial criticism, basically on the ground that its standards are far too low to be of any real value to the consumer. For example, the government itself reported in 1970 that every one of the 230 garments recovered from 159 burn case studies involving 17 deaths passed the prevailing test for rapid and intense burning. Plaintiffs' experts regularly argue, and sometimes prove, that even ordinary toilet paper or newspaper will pass this test.

W. KBsTON, supra note 49 , at 373 .

${ }^{128}$ See generally Wilson v. Piper Aircraft Corp., 282 Or. 61, 577 P.2d 1322 (1978); UNIporm Product Liability LaW \& 107 and analysis (U.S. Dep't of Commerce Draft 1979), reprinted in 44 Fed. Reg. $3007-08$ (1979). The approach to this issue in the final draft is different. See MOder UNIForm Product Liability Acr § 108 and analysis (U.S. Dep't of Commerce 1979), reprinted in 44 Fed. Reg. 62,714, 62,730-31 (1979) [hereinafter cited as MUPLA]. 
defining defectiveness (the "proper" mix of safety and its tradeoffs) are especially great. ${ }^{198}$ In these circumstances, particularly if many in the industry have come to treat the provision as the proper safety norm, proof of compliance with the regulation or statute ordinarily should be deemed to be conclusive proof of good faith and hence a conclusive defense to a punitive damages claim.

2. Causal Factors Apart from Defect. a. In general. It is axiomatic that a manufacturer will not be held liable for losses that it did not cause, whether or not it sold the product in flagrant disregard of its dangers. If the plaintiff's injury is not fairly traceable to the alleged product defect, there can be no liability for damages of any type. ${ }^{197}$ If the injury results from a combination of a defect and serious product abuse by the plaintiff or someone else, however, the problem becomes much more difficult.

b. Product misuse and contributory fault. The real world environment into which products are sold informs the manufacturer that they will be subjected to occasional and moderate abuse, and warning and design choices must reflect such expectable events. ${ }^{198}$ Yet most persons are not prepared to pay the high price that would result if the law required that products be designed to withstand the most severe abuse; probably most would rather pay lower prices and shoulder the responsibility for this class of risks themselves. ${ }^{199}$ Thus, where a product fails from substantial abuse, the cause of the accident usually is deemed to be "unforeseeable,"

108 Many automobile safety regulations imposed by the National Highway Transportation Safety Administration ("NHTSA") are probably of this type. For this reason, even the deliberate reduction in safety to the minimum level required in a newly-adopted safety standard of this type should be considered acceptable behavior in most cases. Evidence that Chrysler "manufactured down" to new 30 m.p.h. rear crash-test standards that NHTSA adopted in 1976, however, apparently was influential in a jury's decision to assess $\$ 3$ million in punitive damages against the company for its design of the 1977 Volare's fuel system. See Fort Lauderdale News \& Sun-Sentinel, Aug. 29, 1981.

192 See Turney v. Ford Motor Co., 94 IIl. App. 3d 678, 687, 418 N.E.2d 1079, 1087 (1981). See also Sabich v. Outboard Marine Corp., 131 Cal. Rptr. 703, 706 (1976) ("It is inconceivable that anyone should be held civilly liable for an injury which he did not cause, whether he be charged with negligence, intentional wrongdoing, or conduct giving rise to absolute liability."), cause dismissed by stipulation, 60 Cal. App. 3d 591 (1977). See generally Klemme, The Enterprise Liability Theory of Torts, 47 U. Colo. L. REv. 153, 163 (1976); Owen, The Highly Blameworthy Manufacturer: Implications on Rules of Liability and Defense in Products Liability Actions, 10 IND. L. REv. 769, 777-87 (1977).

198 See generally W. KEETON, supra note 49, at 338-46, 408-24; Note, Overuse in Products Liability, 57 NEB. L. REv. 817 (1978).

100 Cf. Owen, supra note 31, at 714 (noting "the apparent unfairness of forcing manufacturers to internalize consumer 'madness' in putting products to unpredictably dangerous use"). 
and the manufacturer is relieved of responsibility. ${ }^{200}$ An alternate approach, at least in cases where it is the plaintiff who has abused the product, is to find his conduct to have been the "sole proximate cause" of the accident. ${ }^{201}$ The equities are different, however, and the proper resolution less clear, when the plaintiff's injury is traceable beyond a product defect to some flagrant misbehavior by the manufacturer.

The classic doctrinal resolution of the problem in compensatory damages cases involving reckless misconduct by the defendant was to hold him liable for the results of the plaintiff's negligent, but not reckless, contributory misbehavior. ${ }^{202}$ Whether this general doctrine should prevail in the punitive damages context is difficult to say. The trend in compensatory damages cases is toward a comparative apportionment of fault and damages and away from the all-or-nothing principles of former times. ${ }^{203}$ Yet even under systems of pure comparative fault, a sole proximate cause defense probably should be retained as a total bar to punitive damages in certain situations of extreme consumer fault. ${ }^{204}$ Where the plaintiff plainly brought the accident upon himself by recklessly throwing himself into the arms of danger, punishing the defendant on top of awarding the plaintiff reduced compensatory damages often seems oddly out of place. ${ }^{205}$ This is particularly true in cases where the

${ }^{200}$ See, e.g., Hegwood v. General Motors Corp., 286 N.W.2d 29, 30 (Iowa 1979) (tire blowout at 110-120 m.p.h.). See note 198 supra.

201 See, e.g., Kroon v. Beech Aircraft Corp., 628 F.2d 891, 893-94 (5th Cir. 1980); McCarty v. F.C. Kingston Co., 22 Ariz. App. 17, 18, 522 P.2d 778, 779 (1974).

${ }_{203}$ See Restatement, supra note 35, § 503(1); Landes \& Posner, supra note 76, at 134 (arguing that the rule generally is efficient). See also Owen, supra note 197, at 787-93. Assumption of risk is also classically held to bar recovery for even reckless misconduct, see id. at 789-91. This defense usually arises in cases of obvious dangers, see Vargus v. Pitman Mfg. Co., 510 F. Supp. 116, 119 (E.D. Pa. 1981), which have been addressed above. See tert and notes at notes 175-187 supra.

103 See generally V. Schwartz, Comparative Negligence (1974). Some limitations of the comparative fault doctrine are examined in Twerski, The Use and Abuse of Comparative Negligence in Products Liability, 10 IND. L. REv. 797 (1977); Walkowiak, Reconsidering Plaintiff's Fault in Product Liability Litigation: The Proposed Conscious Design Choice Exception, 33 VAND. L. REv. 651 (1980).

${ }^{204}$ See Kroon v. Beech Aircraft Corp., 628 F.2d 891 (5th Cir. 1980); V. SchwarTz, supra note $203, \S 4.4$, at 91 . Cf. MUPLA, supra note $195, \S 120(\mathrm{~B})(8) \&$ analysis (providing for the reduction of such damages where "the harm suffered by the claimant was also the result of the claimant's own reckless disregard for personal safety"), reprinted in 44 FED. REg. at $62,748-49$.

${ }^{20 s}$ Sturm, Ruger \& Co. v. Day, 594 P.2d 38 (Alaska 1979), on rehearing, 615 P.2d 621 (1980), leaves me with this impression, as does Silkwood v. Kerr-McGee Corp., 485 F. Supp. 566 (W.D. Okla. 1979), rev'd in part, No. 79-1894 (10th Cir. Dec. 11, 1981). Even where the plaintiff seriously and consciously misbehaves, however, punitive damages may be appropri- 
product was not clearly and palpably defective and where the manufacturer's bad faith is not plainly evident (the "close call" cases); in situations such as these, the reckless misconduct of the plaintiff reinforces the preclusion of punitive damages in any amount. Where the misconduct of both the manufacturer and the user is clearly flagrant and extreme, however, and the causal connection is fairly traceable to both in substantial measure, it may be that a moderate award of punitive damages-perhaps limited to an amount approximating attorneys' fees and other costs of litigation $^{208}$ — would be in order.

\section{Problems of Measurement and Control}

\section{A. Method and Problems of Measurement}

The amount of punitive damages generally is determined by the jury upon a consideration of three factors: the degree of reprehensibility of the defendant's misconduct, the nature and extent of the plaintiff's injury, and the amount of the defendant's wealth. ${ }^{207}$ Ostensibly because of the jury's role as the conscience of the community, yet in fact largely because of the impossibility for reasoned judicial review of such a vague issue as reprehensibility, most courts purport to vest the jury with wide discretion in determining the amount of punishment. ${ }^{208}$ In practice, however, especially in cases against institutional defendants, there appears to be a growing trend to subject such awards to greater judicial scrutiny. ${ }^{209}$

ate in cases of truly intentional wrongdoing by the manufacturer, as in many cases of fraud.

${ }^{208}$ See Restatement, supra note 35 , \$ 908 comment f.

207 "In short, crassness of conduct may govern the amount of award commensurate with a defendant's financial ability." Silkwood v. Kerr-McGee Corp., 485 F. Supp. 566, 591 (W.D. Okla. 1979), rev'd in part on other grounds, No. 79-1894 (10th Cir. Dec. 11, 1981). See text and note at note 44 supra.

${ }^{203}$ See Armstrong v. Republic Realty Mortgage Corp., 631 F.2d 1344, 1353 (8th Cir. 1980) ("'matter of punitive damages is so "purely and peculiarly one for the jury's discretion" that only in an extreme case will the appellate court interfere" ") (quoting Hoene v. Associated Dry Goods Corp., 487 S.W.2d 479, 486 (Mo. 1972)); cf. Maxey v. Freightliner Corp., 450 F. Supp. 955, 966 (N.D. Tex. 1978) ("This court will not substitute its judgment for the jury's."), aff'd, 623 F.2d 395 (5th Cir.), rehearing en banc granted, 634 F.2d 1008 (5th Cir. 1980).

${ }^{209}$ Despite the observation of the Maxey court, see note 208 supra, it did in fact strike the jury's $\$ 10$ million award altogether. 450 F. Supp. at 964 . See also Sturm, Ruger \& Co. v. Day, 594 P.2d 38, 48 (Alaska 1979) (reducing $\$ 2.9$ million jury award to $\$ 250,000$ and observing that "judicial scrutiny over the awards provides a partial justification for allowing such awards in the first place. The spectre of bankruptcy and excessive punishment can be in part dispelled to the extent that trial and appellate courts exercise their powers of review."), on rehearing, 615 P.2d 621 (1980); Wangen v. Ford Motor Co., 97 Wis. 2d 260, 298, 
The general principles of measurement and jury discretion described above have tended to work satisfactorily in most traditional contexts in which punitive damages have been awarded, such as those involving fraud, conversion, assault, defamation, seduction, and trespass. When one person deprives another of his rights in one of these contexts, the jury is usually a good gauge of the community's pulse on whether the defendant acted with malice or reckless abandon, whether the misconduct requires punishment in addition to the payment of compensatory damages and, if so, the amount of punitive damages necessary to serve both as an appropriate punishment to the offender and as an example to others. Especially in former times, when jurors were selected because of their familiarity with the parties and the facts of the particular dispute, ${ }^{210}$ their intuitive sense of how great a need existed for further "justice" than the law permitted through compensatory damages was well suited to the situation. ${ }^{211}$ The limited wealth of most human defendants usually provided a sufficient cap for such awards, which in today's dollars might reach at a maximum several thousand dollars-enough to make a major dent in the net worth of all but the most wealthy malefactor.

Such is not the state of affairs today, however, in products liability actions against major manufacturers. The jurors, of course, can know little of the dispute, and the plaintiff's lawyer often will seek to include on the jury only persons who know very little about how corporate enterprises really function. Few if any of the jurors will have any firm idea of what the manufacturer's financial sheet figures really mean ${ }^{212}$ or of what effect a certain level of punitive damages will have on the financial and operating affairs of the enterprise.

Added to this threshold problem is the fact that "wealth" no longer serves as a clearly limiting factor on the range of jury discretion. Instead, a jury instructed to use the "wealth" of a multimillion or multi-billion dollar corporation as a yardstick in assess-

294 N.W.2d 437, 457 (1980) ("We believe [that] judicial controls . . . will provide for fair administration of punitive damage awards in this state."). See RESTATEMENT, supra note 35, $\S 908$ comment $f$ ("In many states there has been a tightening of control by the appellate courts over discretion of the trier of fact.").

210 See generally Hassett, A Jury's Pre-Trial Knowledge in Historical Perspective: The Distinction Between Pre-Trial Information and "Prejudicial" Publicity, 43 LAW \& CoNTEMP. Probs. 155 (Autumn 1980).

${ }^{211}$ See DuBois, supra note 33, at 347.

212 See text and notes at notes 89-92 supra. 
ing punitive damages is almost forced to think in terms of seven figures, as did the jury in Sturm, Ruger, ${ }^{213}$ or eight figures, as in the Maxey case, ${ }^{214}$ or even nine figures, as in Grimshaw. ${ }^{215}$ After all, how can a jury otherwise expect to make its punitive assessment teach a meaningful lesson to a company "making" millions of dollars every day? Thus, the former "capping" effect of wealth as a yardstick, and even the very understanding of that concept, are usually absent in the modern products liability case. ${ }^{\mathbf{2 1 6}}$

Moreover, the notion of institutional culpability is very different from that of human guilt. Although a jury might have a good intuitive sense of the degree of moral blame that properly attaches to a punch in the nose or to repeated trespasses over another's land, the ideas of institutional responsibility and irresponsibility, and the measurement of irresponsibility on a scale that at some point reads "flagrant," involve complex political, philosophical, and practical considerations that may reach beyond the ken of many jurors. ${ }^{217}$

213 The amount of the jury's award was $\$ 2.9$ million. 594 P.2d at 41 .

214 The amount of the jury's award was $\$ 10$ million. $450 \mathrm{~F}$. Supp. at 957.

215 The amount of the jury's award was $\$ 125$ million. 119 Cal. App. 3d at 771, $174 \mathrm{Cal}$. Rptr. at 358. Note the court's discussion of the asserted excessiveness of the remitted amount of $\$ 3.5$ million:

Nor was the reduced award excessive taking into account defendant's wealth and the size of the compensatory award. Ford's net worth was $\$ 7.7$ billion dollars and its income after taxes for 1976 was over $\$ 983$ million. The punitive award was approximately .005 percent of Ford's net worth and approximately .03 percent of its 1976 net income. Id. at 820, 174 Cal. Rptr. at 388-89.

216 The problem is aggravated substantially in "mass disaster" cases where the manufacturer faces a multiplicity of punitive damages claims. See note 227 and text and note at note 235 infra.

217 In fact, the study of corporate responsibility and culpability remains in its infancy even among scholars of law and corporate behavior. Recent literature on point includes $M$. Clinard \& P. Yeager, Corporate Crime (1980); M. Ermann \& R. Lundman, Corporate and Governmental Deviance (1978); Coffee, Beyond the Shut-Eyed Sentry: Toward a Theoretical View of Corporate Misconduct and an Effective Legal Response, 63 VA. L. REv. 1099 (1977); Coffee, Making the Punishment Fit the Corporation: The Problems of Finding an Optimal Corporation Criminal Sanction, 1 N. ILL. U.L. REv. 3 (1980) [hereinafter cited as Making Punishment Fit]; Crane, Commentary: The Due Process Considerations in the Imposition of Corporate Liability, 1 N. ILL. U.L. Rev. 39 (1980); Demsetz, Social Responsibility in the Enterprise Economy, 10 Sw. U.L. REv. 1 (1978); Engel, An Approach to Corporate Social Responsibility, 32 Stan. L. REv. 1 (1979); Friedman, Some Reflections on the Corporation as Criminal Defendant, 55 Notre DAME LAw. 173 (1979); Stone, The Place of Enterprise Liability in the Control of Corporate Conduct, 90 YAie L.J. 1 (1980); WhiteCollar Crime, 17 AM. CRIM. L. REv. 409 (1980); Developments in the Law-Corporate Crime: Regulating Corporate Behavior Through Criminal Sanctions, 92 HARv. L. Rev. 1227 (1979); Note, Corporate Homicide: A New Assault on Corporate Decision-making, 54 NoTRE DAME LAw. 911 (1979) (discussing Indiana criminal prosecution of Ford for Pinto de- 
The problem, of course, is aggravated by the complexity of the engineering choices lying behind the corporate acts. A rose is often not a rose in such an environment, and what looks like acceptable if not praiseworthy conduct to one person may look flagrantly improper to another: one person's sound engineering is another person's trading lives for profits.

Compounding these problems of comprehension and definition is one of process. One of the classic words used in older cases to describe the requisite misconduct for punitive damages was "outrageous,"218 a word still used on occasion even in products cases. ${ }^{219}$ The word appears to imply that the jury must be enraged by the wrongfulness of the defendant's conduct before it may award punitive damages at all. Because the amount of such an award is supposed to increase with the degree of moral reprehensibility, the amount presumably should increase in line with the jury's sense of outrage. Carrying this reasoning to its conclusion, when a jury's rage has been whipped into a frenzy, it is authorized to tax the largest possible award of punitive damages-probably in an amount just short of bankruptcy.

The problem is that, in theory at least, we require that our tribunals render their decisions upon calm and disinterested reflection, free from emotion. Indeed, a common basis for reversal or remittitur of a punitive damages award is a finding that it was based on "passion or prejudice."220 The apparent paradox thus results that a punitive damages claim may not lie unless the jury is outraged, yet if the jury is outraged its verdict must be reversed: the standard of liability therefore appears to include the basis for its own reversal. ${ }^{221}$ The paradox is in theory resolved by instructing jurors to remain dispassionate while finding outrage in the defendant's acts, yet one may question how effectively the average human mind can separate theoretical outrage from the emotional kind.

sign); Note, Decisionmaking Models and the Control of Corporate Crime, 85 YALE L.J. 1091 (1976).

s18 See Restatzment, supra note 35 , $\$ 908(1)$.

210 See, e.g., American Motors Corp. v. Ellis, 403 So. 2d 459, 467 (Fla. Dist. Ct. App. 1981); Wangen v. Ford Motor Co., 97 Wis. 2d 260, 299, 294 N.W.2d 437, 457 (1980); Wussow v. Commerical Mechanisms, Inc., 97 Wis. 2d 136, 154, 155, 293 N.W.2d 897, 906, 907 (1980).

${ }^{220}$ See, e.g., Sturm, Ruger \& Co. v. Day, 594 P.2d 38, 48 (Alaska 1979), on rehearing, 615 P.2d 621, 624 (1980).

${ }^{221}$ See Owen, supra note 7, at 1320 n.304. 
Perhaps the inherent "volatility"222 of the punitive damages issue demonstrated by this paradox will require the adoption of arbitrary limits to punitive damages awards against manufacturers to keep such awards within reasonable bounds. One such approach is the reasonable relationship or ratio test employed in many states. ${ }^{223}$ Most courts and many juries at least implicitly have been using this approach, as demonstrated by the fact that the ratio of punitive to compensatory damages approved on appeal in serious injury or death cases of this type only rarely has exceeded 1.5 or 2:1.224 In Grimshaw, for example, the ratio (as remitted) was 1.4:1. ${ }^{225}$ Another control device would be to place an arbitrary dollar limit on the amount of punitive damages awardable to any one plaintiff. With the exception of Grimshaw, only one appellate court in a products case has approved a punitive damages award to a single plaintiff in excess of $\$ 1$ million, ${ }^{228}$ and perhaps that amount should generally be considered a natural cap for such awards. 227

${ }_{222}$ See Georgie Boy Mfg., Inc. v. Superior Court, 115 Cal. App. 3d 217, 225, 171 Cal. Rptr. 382, 386 (1981). Cf. In re Paris Air Crash, 622 F.2d 1315, 1323 (9th Cir.) ("The frequently violent and dramatic circumstances of accidents that lead to wrongful death actions not only would pose this danger of extreme awards, but also might increase the temptation for a jury to award punitive damages even when concrete elements of fraudulent or intentional wrongdoing are absent."), cert. denied, 449 U.S. 976 (1980).

${ }^{223}$ See Rosener v. Sears Roebuck \& Co., 110 Cal. App. 3d 740, 753, 168 Cal. Rptr. 237, 245 (1980) ("Without the reasonable relationship instruction, the discretion of the jury becomes simply limitless."), appeal dismissed, 450 U.S. 1051 (1981); text and note at note 45 supra. See also Miley v. Oppenheimer \& Co., 637 F.2d 318, 331 (5th Cir. 1981) (adopting treble damages standard for determining excessiveness of punitive damages verdict in case involving account "churning" by stockbroker); Coffee, Making Punishment Fit, supra note 217 , at 29 (proposing "a treble damages formula as a partial substitute for the class action" in "Pinto-type" litigation). See generally Wangen v. Ford Motor Co., 97 Wis. 2d 260, 303 n.26, 294 N.W.2d 437, 459 n.26 (1980).

224 See, e.g., Gillham v. Admiral Corp., 523 F.2d 102, 104 (6th Cir. 1975) (punitive damages, plus attorneys' fees, $\$ 150,000$; compensatory damages, $\$ 125,000$; ratio-1.2:1), cert. denied, 424 U.S. 913 (1976); Gryc v. Dayton-Hudson Corp., 297 N.W.2d 727, 729 (Minn.) (punitive damages, $\$ 1$ million; compensatory damages, $\$ 750,000$; ratio-1.3:1), cert. denied, 449 U.S. 921 (1980); Leichtamer v. American Motors Corp., 424 N.E.2d 568, 573 (Ohio 1981) (combined punitive damages, $\$ 1.1$ million; combined compensatory damages, $\$ 1.1$ million; ratio-1:1). But see Dorsey v. Honda Motor Co., 655 F.2d 650, 652 (5th Cir. 1981) (punitive damages, $\$ 5$ million; combined compensatory damages, $\$ 825,000$; ratio-6.1:1); Rinker v. Ford Motor Co., 567 S.W.2d 655, 658 (Mo. Ct. App. 1978) (punitive damages, $\$ 460,000$; compensatory damages, $\$ 100,000$; ratio-4.6:1). By statute, Connecticut now limits punitive damages in products cases to twice the plaintiff's actual damages. See note 247 infra.

${ }^{225}$ The remitted punitive damages were $\$ 3.5$ million, the compensatory about $\$ 2.5$ million. 119 Cal. App. 3d at 771-72 \& n.1, 174 Cal. Rptr. at 358 \& n.1.

${ }^{228}$ Dorsey v. Honda Motor Co., 655 F.2d 650, 656 (5th Cir. 1981) (\$5 million).

${ }^{227}$ This conclusion is buttressed by the apparent fact that the highest penalty author- 
At the very least, the "outrage" paradox requires courts to scrutinize with special care punitive damages verdicts that look high by any measure. Thus the Grimshaw trial court certainly was correct in remitting the $\$ 125$ million verdict by a very large proportion. The court also would appear to have been acting well within reason had it taken the further step of reversing completely on the grounds of passion or prejudice; ${ }^{228}$ whether such a result was appropriate on the facts is difficult to tell from the published opinion. Perhaps the basic lesson from the outrage paradox is that punitive damages awards walk a tight line of propriety vel non in any type of case. ${ }^{229}$ In a products liability case against a corporate manufacturer, the inherent juror bias, the complexities of the factual questions, and the vagueness of the legal standards create an atmosphere especially ripe for an effective plaintiff's advocate to stir the hearts and inflame the passions of any jury. ${ }^{230}$

ized by statute for breach of the criminal law is $\$ 1$ million. Cf. Coffee, Making Punishment Fit, supra note 217, at 7, 36 (\$1 million maximum fine for antitrust violations).

To deal with situations involving a multiplicity of punitive damages claims, other arbitrary control devices may be in order. As the total punitive damages assessed against the company in different actions mount, there should come a point when the aggregate of such punishment will be deemed sufficient as a matter of law. See In re Northern Dist. "Dalkon Shield” IUD Prods. Liab. Litig., 521 F. Supp. 1188, 1193 (N.D. Cal. 1981), full op. issued, No. 80-2213 (Nov. 5, 1981). As a guide for knowing when that point is reached, a court might look to some arbitrary, aggregate cap-for instance, the lesser of $\$ 5$ million or $5 \%$ of net worth-after which it could limit such damages to the plaintiff's attorneys' fees and other costs of litigation. See Owen, supra note 7, at 1325. Although the legislature is clearly the preferable forum for determining the proper amounts for such general limits, the courts may be forced to make such decisions due to the exigencies of this type of litigation if the legislatures do not act. See note 247 infra.

H.R. 5214, 97th Cong., 1st Sess. (1981), introduced by Rep. Norman D. Shumway (R. Cal.), adopts several of the control approaches discussed above. Section 11 limits punitive damages to the lesser of twice the plaintiff's compensatory damages or $\$ 1$ million and sets an aggregate cap at the lesser of $\$ 5$ million or five percent of net worth, after which such damages are limited to the lesser of attorney's fees or double compensatory damages.

Class action certification in appropriate cases might also help to avoid the risk of overpunishment. See In re Northern Dist. "Dalkon Shield" IUD Prods. Liab. Litig., 521 F. Supp. 1188, 1192-94 (N.D. Cal. 1981), full op. issued, No. 80-2213 (Nov. 5, 1981). See also text and note at note 249 infra. But cf. Coffee, Making Punishment Fit, supra note 217, at 28 (citing impracticalities of class actions in products cases).

228 After Egan v. Mutual of Omaha Ins. Co., 24 Cal. 3d 809, 598 P.2d 452, 157 Cal. Rptr. 482 (1979) (reversing $\$ 5$ million punitive damages verdict for excessiveness), appeal dismissed, 445 U.S. 912 (1980), one might have expected such a result.

229 See text and note at note 209 supra.

230 See text and note at note 61 supra. 


\section{B. Increasing Judicial Control}

Against this background of potential jury whim is a clear trend by the courts to take firmer hold of matters relating to punitive damages in products cases. In recognition of the array of problems endemic to the use of punitive damages in this context, some courts of late have begun to exert stricter control over the process of determining such awards, from discovery safeguards ${ }^{231}$ and pretrial rulings ${ }^{232}$ through remittitur ${ }^{233}$ or reversal on appeal. ${ }^{234}$ Several courts that recently have approved for the first time awards of punitive damages in products liability cases have emphasized the importance of firm trial and appellate court control to reduce the added risks of abuse-particularly the threat of over-punishment from multiple awards for a single product mistake. ${ }^{235}$ This development is of crucial importance, ${ }^{236}$ one that may well be necessary to prevent such awards from violating a corporation's due process rights. ${ }^{237}$

1. Tightening the Legal Standards. I have discussed above the importance of refining the definition of the standard of misconduct in products liability cases and the usefulness of separating the culpability issue into its various components for proof, argument, and analysis. ${ }^{238} \mathrm{~A}$ similar breakdown of the considerations pertinent to the determination of the amount of such awards is at least as important. Searching for a means to narrow and clarify the focus of inquiry in such litigation, at least two states by legislation, ${ }^{238}$

${ }^{231}$ See text and notes at notes $252-260$ infra.

${ }^{232}$ See text and notes at notes 261-266 infra.

2ss See text and notes at notes 271-273 infra.

234 See text and note at note 270 infra.

${ }^{235}$ See Sturm, Ruger \& Co. v. Day, 594 P.2d 38, 48 (Alaska 1979), on rehearing, 615 P.2d 621, 624 (1980); American Laundry Mach. Indus. v. Horan, 45 Md. App. 97, 113-15, 412 A.2d 407, 417-19 (1980); Rinker v. Ford Motor Co., 567 S.W.2d 655, 668-69 (Mo. Ct. App. 1978); Wangen v. Ford Motor Co., 97 Wis. 2d 260, 306-07, 294 N.W.2d 437, 461 (1980). See also text and note at note 249 infra.

238 See Mallor \& Roberts, supra note 33, at 670 ("[T]he very power of the remedy demands that judges exercise close control over the imposition and assessment of punitive damages.").

${ }^{237}$ Due process arguments have fared poorly in the products liability-punitive damages context, however. See, e.g., Sturm, Ruger \& Co. v. Day, 594 P.2d 38, 46 (Alaska 1979), on rehearing, 615 P.2d 621 (1980); Grimshaw v. Ford Motor Co., 119 Cal. App. 3d 737, 811-12, 174 Cal. Rptr. 348, 383-84 (1981); Toole v. Richardson-Merrell, Inc., 251 Cal. App. 2d 689, 716-17, 60 Cal. Rptr. 398, 417-18 (1967).

${ }^{238}$ See text and notes at notes 93-125 supra.

${ }^{239}$ See Minn. Stat. Ann. $§ 549.20$ (3) (West Supp. 1981); Or. Rev. Stat. $§ 30.925$ (1979). 
several courts, ${ }^{240}$ and the Commerce Department in its Model Uniform Products Liability Act ${ }^{241}$ have adopted some version of the list of factors I proposed in my earlier article ${ }^{242}$ to guide courts and juries in deciding the amount of punitive liability to assess. ${ }^{243} \mathrm{Al}-$ though consideration of these factors against the factual context of a case cannot of course reduce the question of amount to mathe-

${ }^{240}$ See, e.g., Sturm, Ruger \& Co. v. Day, 594 P.2d 38, 48 n.17 (Alaska 1979), on rehearing, 615 P.2d 621 (1980); Wangen v. Ford Motor Co., 97 Wis. 2d 260, 305, 294 N.W.2d 437, 460 (1980).

${ }^{211}$ See MUPLA, supra note 195, § 120(B), reprinted in 44 FED. REg. at 62,748.

242 The factors were outlined there as follows:

In summary, proper measurement of a punitive damages award in a products liability case should be furthered by careful consideration of the following factors:

(1) the amount of the plaintiff's litigation expenses;

(2) the seriousness of the hazard to the public;

(3) the profitability of the marketing misconduct (increased by an appropriate multiple);

(4) the attitude and conduct of the enterprise upon discovery of the misconduct;

(5) the degree of the manufacturer's awareness of the hazard and of its excessiveness;

(6) the number and level of employees involved in causing or covering up the marketing misconduct;

(7) the duration of both the improper marketing behavior and its cover-up;

(8) the financial condition of the enterprise and the probable effect thereon of a particular judgment; and

(9) the total punishment the enterprise will probably receive from other sources. Owen, supra note 7 , at 1319.

${ }^{243}$ One factor that apparently has influenced juries more than the courts is item (3), the profitability of the marketing misconduct. One of the Grimshaw jurors interviewed after the trial explained the jury's rationale in selecting $\$ 125$ million as the amount for the punitive award: "Mr. Greene . . . recalls bringing up the $\$ 125$ million figure himself. He reasoned that if Ford had saved $\$ 100$ million by not installing safe tanks, an award matching that wouldn't really be punitive. So he added $\$ 25$ million." Wall St. J., Feb. 14, 1978, at 12, col. 2. See also Sturm, Ruger \& Co. v. Day, 594 P.2d 38, 50 (Alaska 1979), on rehearing, 615 P.2d 621, 626 (1980) (dissenting opinions), where the jury's punitive award of $\$ 2.9$ million was roughly the product of the number of revolvers sold (about 1.5 million) times the cost per unit (\$1.93) that would have been necessary "to cure the defect."

How the profitability of the misconduct should figure into the calculation of a punitive damages award is an aspect of the broader question whether the defendant should be forced to redress the totality of its wrong to the public in a single action and a single punitive damages award. Implicitly, the Grimshaw and Sturm, Ruger courts both thought not. A federal court expressly addressing the question agreed:

To conclude that this particular victim may collect punitive damages on behalf of that immeasurable group of Aralen consumers is folly ... . In the final analysis, . . the computation of the punitive damages verdict, if any, must be a reasonable sum in relation to the defendant's conduct vis-a-vis the plaintiff.

Hoffman v. Sterling Drug, Inc., 374 F. Supp. 850, 856 (M.D. Pa. 1974). This view probably is correct in that it relates the punitive award to the plaintiff's injury consistent with traditional doctrine, reduces substantially the incentive to race to the courthouse, and anticipates a multiplicity of similar actions that together will result in many smaller "stings" to the manufacturer. See note 227 supra. 
matical precision, they serve at least to clarify the questions of why the act was very wrong and what may be necessary to discourage such behavior in the future.

2. Tightening Up on Procedural Control. a. Bifurcation. I continue to believe that judges alone should determine at least the amount of punitive awards in products cases, ${ }^{244}$ as several commentators ${ }^{245}$ and the Model Act ${ }^{246}$ have proposed. Ideally, as apparently directed by statute in Connecticut, ${ }^{247}$ the trial should be bifurcated to accomplish this result. Thus the jury would pass on liability for compensatory damages and their amount and perhaps on liability for a punitive award as well. If necessary, the trial judge, sitting without a jury, would then hold a second hearing on punitive damages alone. Under this bifurcated procedure, complicated financial testimony that might prejudice the jury on the defect question would be heard only by the trial judge. Also relevant at this second stage of trial would be any additional evidence presented by either party relevant to the aggravation or mitigation of guilt or otherwise relevant at this stage only. ${ }^{248}$

One such type of evidence relevant to amount, of crucial importance in many "mass disaster" products liability cases, is the "poverty" evidence a manufacturer, for obvious tactical reasons, may be reluctant to introduce before a jury. If the manufacturer is facing many lawsuits of a similar type, as in the Dalkon Shield litigation, the total "punishment" it already has suffered and is likely in the future to receive for the same misconduct (measured by judgments and settlements for punitive-and perhaps compensatory-damages), substantially reduces the appropriate amount of

24 See Owen, supra note 7, at 1320 . Similar to the sentencing of criminals, the determination of amount has aptly been described as a "quasi-judicial" function. See Prince v. Peterson, 538 P.2d 1325, 1329 (Utah 1975) (libel and slander case).

${ }^{245}$ See, e.g., DuBois, supra note 33, at 352-53; Fulton, supra note 33 at 130; Mallor \& Roberts, supra note 33 , at 663-66.

${ }^{246}$ See MUPLA, supra note 195, § 120(B), reprinted in 44 FED. REG. at 62,748.

${ }^{247}$ Conn. Gen. Stat. Ann. § 52-240b (West Supp. 1981) ("If the trier of fact determines that punitive damages should be awarded, the court shall determine the amount of such damages not to exceed an amount equal to twice the damages awarded the plaintiff."). See also CaL. Crv. Code $\S 3295$ (West 1981) and OR. REv. Stat. $\S 30.925(2)$ (1979), respectively permitting and requiring the plaintiff to establish a prima facie case on punitive damages liability prior to the admission of evidence on the defendant's financial condition.

${ }^{248}$ See Wangen v. Ford Motor Co., 97 Wis. 2d 260, 323, 294 N.W.2d 437, 468 (1980) (Coffey, J., dissenting). Cf. Restatement, supra note 35, § 908 comment $\mathrm{f}$ ("Sometimes procedural techniques are utilized to prevent abuse of a claim for punitive damages when it becomes apparent that they are not warranted and the claim was made for the purpose of introducing prejudicial evidence that would otherwise not be admissible."). 
punishment in the case at bar. ${ }^{249}$ Other relevant yet sensitive evidence that the manufacturer fairly might wish to avoid presenting to the jury at the compensatory damages liability stage of the proceedings, such as cost-benefit studies, ${ }^{200}$ post-sale product improvements, or the reliance by executives upon advice of counsel, ${ }^{251}$ could be heard at this time as well.

b. Pretrial showings and evidentiary rulings at trial. Although apparently not all courts have the power to do so, ${ }^{262}$ at least one court has followed the approach authorized by statute in California ${ }^{263}$ of requiring a plaintiff to make a prima facie showing of a manufacturer's liability for punitive damages before pretrial discovery of wealth may proceed. ${ }^{254}$ Because considerable financial data on publicly-held corporations is available to plaintiffs' counsel in annual reports and 10-K reports filed with the SEC, ${ }^{255}$ this form of pretrial protection usually will have little impact on the availability of such information. Where such information is sought through discovery channels, ${ }^{258}$ however, the requirement will have the salutary effect of forcing the punitive damages issue at an early

349 Roughly 1600 suits are presently pending against A.H. Robins Co., the manufacturer of the Dalkon Shield. In re Northern Dist. "Dalkon Shield" Prods. Liab. Litig., 521 F. Supp. 1188, 1193 (N.D.Cal. 1981), full op. issued, No. 80-2213 (Nov. 5, 1981). Compensatory damages claimed in these cases total more than $\$ 500$ million, $i d$. at 1191 , and punitive damages claimed total some $\$ 2,350,597,000$, id. at 1193 . The company's net worth is $\$ 280,394,000$. Id. at 1191. See text and notes at notes 227, 235 supra. See generally United School Dist. No. 490 v. Celotex Corp., 629 P.2d 196, 206 (Kan. Ct. App. 1981); Owen, supra note 7, at 132225.

${ }^{230}$ See text and notes at notes 264-266 infra.

2s1 On the "defense" of reliance on advice of counsel, see Rosener v. Sears Roebuck \& Co., 110 Cal. App. 3d 740, 754, 168 Cal. Rptr. 237, 245 (1980), appeal dismissed, 450 U.S. 1051 (1981); Levit, Punitive Damages: Yesterday, Today and Tomorrow, 1980 INs. L.J. 257, 265.

${ }_{232}$ See Nichols v. Hoeke, 297 N.W.2d 205 (Iowa 1980).

${ }^{253}$ See Cal. Crv. Code $\S 3295$ (c) (West 1981).

${ }^{284}$ Leidholt v. District Court, 619 P.2d 768, 771 (Colo. 1980). See generally Note, Pretrial Discovery of Net Worth in Punitive Damages Cases, 54 S. CAL. L. RBv. 1141, 1148-49 (1981).

${ }^{285}$ See 17 C.F.R. $\$ \S 229.20,249.310$ (1981), implementing 15 U.S.C. $\$ \S 78 \mathrm{~m}, 78 \mathrm{o}(\mathrm{d})$ (1976 \& Supp. IV 1980). Under section 229.20 , a corporation registering with the Securities and Exchange Commission is required annually to provide a description of its business, including its current financial situation; a description of the physical property held by it; a list of its directors and officers; a table showing all remunerations paid to directors and officers; a description of any relevant legal proceedings to which it is a party; a list of all persons owning more than five percent of its securities; information as to the market prices paid for its securities; a discussion of management of its finances and operations; and various other information.

${ }^{286}$ As might be necessary for very recent information on a publicly-held corporation and for general financial information on a privately-held concern. 
stage.

Because a single punitive damages award can amount to millions of dollars, and because the likelihood of such assessments is less predictable than compensatory damages awards, a prima facie ruling on punitive damages at an early stage will help avoid the unnecessary expenditure of considerable sums for the construction of an elaborate punitive damages defense. ${ }^{257}$ Such a showing could be postponed until shortly before the trial, when a plaintiff quite easily could summarize his case on punitive damages at a special hearing without tainting for the jury the main case on compensatory damages. Because of the growing frequency of punitive damage claims, ${ }^{258}$ and because such claims only infrequently are well supported, ${ }^{268}$ such a procedure should save time and expense and also keep away from the jury inflammatory issues and arguments that are unsupported by the evidence. ${ }^{280}$

257 See note 247 supra.

${ }^{288}$ One judge has noted the "present-day practice of seeking punitive damages in substantially all damage actions, and what will reasonably be termed the explosion of punitive damages awards." Rosener v. Sears Roebuck \& Co., 110 Cal. App. 3d 740, 762, 168 Cal. Rptr. 237, 250 (1980) (Elkington, J., concurring) (emphasis in original), appeal dismissed, 450 U.S. 1051 (1981). A former president of the Association of Trial Lawyers of America agrees: "We almost always include a count for punitive damages." Cartwright, Products Liability: Trial Strategy and Tactics, Trial, July 1980, at 38, 39. See also Levit, supra note 251, at 259 ("whereas 25 years ago, the punitive damages case was a rarity, today, it is an anomaly when one sees a complaint which does not seek punitive damages") (emphasis in original). Some plaintiffs' lawyers, however, urge restraint. See, e.g., Igoe, Punitive Damages in Products Liability Cases Should be Allowed, 22 Trial LAw. Guide 24, 29 (1978); Kreindler, Punitive Damages in Aviation Litigation-An Essay, 8 Cum. L. Rev. 607, 617 (1978).

Ford Motor Company's experience demonstrates this point. Prior to 1970, at most one or two products liability lawsuits of the hundreds filed against Ford each year contained a count for punitive damages, for a rate of less than $0.5 \%$ of all such complaints. By 1975 , the rate had risen to $5.4 \%$, and in 1980 it had reached $27.1 \%$. "In addition, to put the number of punitive damages claims in perspective, literally hundreds of the cases we receive each year involve minor property damage. Thus, the actual percentage of punitive damages claims in personal injury cases would be in excess of [these] percentages . . . Eppel Letter, supra note 156 , at app.

${ }^{250}$ This follows from the premise that only on rare occasions is the behavior of manufacturers flagrantly improper, together with the finding that such claims are now very common.

${ }^{280}$ A summary judgment proceeding shortly before trial often could be used effectively in many products cases to screen out punitive damages claims that are plainly devoid of merit-as for example where the product's alleged defectiveness is itself seriously in doubt, or where the defendant can convincingly demonstrate (by affidavit or otherwise) that the claim of corporate "malice" rests principally upon statements in corporate documents that are clearly being misconstrued by plaintiff's counsel. See text and notes at notes 78-88 supra.

Although summary judgment is normally inappropriate on matters involving a person's state of mind, the normal preference for letting such issues go to the jury is offset at least to 
A defendant also should be permitted to make a pretrial argument, perhaps by motion in limine, ${ }^{\mathbf{2 6 1}}$ to ask for the exclusion both of inflammatory evidence that has little or no probative value and of improper arguments that a plaintiff can be expected to put before the jury. Because the punitive damages stakes are so large, the plaintiff's counsel can be expected to tread as closely as possible to, and frequently over, the line of proper evidence and argument in the hope of winning a Grimshaw-type verdict. ${ }^{262}$

Moreover, courts must take more seriously than usual their responsibility at trial to weigh the relevance of such evidence and argument against any undue prejudice likely to be created; ${ }^{263}$ that which appears to tip too heavily toward the latter must be excluded. It was on this ground that the trial court in Grimshaw excluded Ford's cost-benefit memorandum, analyzing a proposed government standard for fuel tank integrity in roll-over situations, that expressly balanced the costs of safety improvements against

some extent in "[c]ases involving malice" where "competing policy considerations" arise. Because "actions that involve questions of malice often are disfavored torts," the "summary adjudication of such claims may be thought of as a useful procedural tool and an effective screening device for avoiding the unnecessary harrassment of defendant." $10 \mathrm{C}$. WRIGHT \& A. MLLER, supra note 70, $\$ 2370$, at 590-92. Although defamation has been the usual context where this principle has been applied, see Comment, The Propriety of Granting Summary Judgment for Defendants in Defamation Suits Involving Actual Malice, 26 VIIL. L. Rev. 470 (1980-81), punitive damages claims against manufacturers appear increasingly to call for careful pretrial scrutiny of just this type. Punitive damages rest of course on "malice" and are often said to be "not favored by the law," and for the many reasons discussed throughout this article there is an increasing cry for subjecting this disfavored "remedy" to especially strict judicial control in products liability actions. See Moore v. Remington Arms Co., 100 Ill. App. 3d 1102, 1114, 427 N.E.2d 608, 617 (1981); see also text and notes at notes 231-237 supra. It thus appears that courts would be well advised in products cases to consider using the summary judgment proceeding on the punitive damages issue as an opportunity to remove what is usually a spurious and emotion-laden issue from the case before trial so that all may look forward to a fair adjudication of those issues that are properly in the case.

${ }^{281}$ See Craven v. Niagara Mach. \& Tool Works, Inc., 417 N.E.2d 1165, 1171-72 (Ind. Ct. App. 1981) (evidence of prior "similar" accidents properly excluded upon motion in limine; no punitive damage issue). See generally Commentary, The Motion in Limine: Pretrial Trump Card in Civil Litigation, 27 U. FuA. L. Rev. 531 (1975).

${ }^{262}$ See Note, Punitive Damages-Justifications, Criticisms and Limitations, 30 DEF. L.J. 189, 204 (1981).

${ }^{283}$ Cf. Lindsay v. Ortho Pharmaceutical Corp., 637 F.2d 87, 94 (2d Cir. 1980) (certain evidence should have been excluded in products liability case under FED. R. Evid. 403 because its probative value was outweighed by the danger of unfair prejudice and confusion). Courts in punitive damages cases should also take an especially hard look at the alleged similarity of other accidents from the same product. Cf. McKinnon v. Skil Corp., 638 F.2d 270, 277 (1st Cir. 1981) (trial court's exclusion of prior accident evidence proper in nonpunitive damages case). See text and note at note 132 supra. 
the benefits in deaths and injuries avoided. ${ }^{264}$ Although this type of analysis by Ford actually was applauded by the Department of Transportation as a helpful step in design safety decision making, ${ }^{265}$ the memo was seized upon by the press as proof of Ford's callous disregard for human life..$^{286}$

c. Judgment on the merits. Many trial courts generally are reluctant to exercise their powers to grant summary judgment, directed verdicts, judgments notwithstanding verdicts, and new trials; such powers, being in derogation of the judgment of the jury, are properly exercised only with studied care. ${ }^{287}$ Yet the risks of an erroneous jury award of punitive damages in a products liability case are so great, as is the probability that the error will contaminate the entire case, that trial courts should give especially

264 This was the so-called Grush-Saunby Report referred to by the court of appeal in Grimshaw. See 119 Cal. App. 3d at 800, 174 Cal. Rptr. at 376. The key cost-benefit calculations appeared in Table 3 of the report:

\section{BENEFITS AND COSTS RELATING TO FUEL LEAKAGE ASSOCIATED WITH THE STATIC ROLLOVER TEST PORTION OF FMVSS 208}

BENEFITS:

Savings: $\quad 180$ burn deaths, 180 serious burn injuries, 2100 burned vehicles.

Unit Cost: $\quad \$ 200,000$ per death, $\$ 67,000$ per injury, $\$ 700$ per vehicle.

Total

Benefit:

$180 \times(\$ 200,000)+180 \times(\$ 67,000)+2100 \times(\$ 700)=\$ 49.5$ million.

cosTs:

Sales:

11 million cars, 1.5 million light trucks.

Unit Cost: $\quad \$ 11$ per car, $\$ 11$ per truck.

Total Cost: $\quad 11,000,000 \times(\$ 11)+1,500,000 \times(\$ 11)=\$ 137$ million.

The table is reproduced and discussed in W. KEEToN, supra note 49, at 490-91. See also Dowie, supra note 2 , at 24 .

${ }^{285}$ Interview with John P. Eppel, supra note 156. The dollar estimates for fatalities and injuries used in the analysis were in fact based upon NHTSA's own cost calculations. See U.S. Dep't of Transportation, Societal Costs of Motor Vehicle Accidents: Preliminary REPORT 1-5 (1972); Eppel Letter, supra note 156.

${ }^{28 B}$ CBS News Correspondent Mike Wallace referred to this report in an interview with Ford's Vice President of Environmental and Safety Engineering: "I find it difficult to believe that top management of the Ford Motor Company is going to sit there and say, 'Oh, we'll buy 2,000 deaths, 10,000 injuries, because we want to make some money or we want to bring in a cheaper car?" "Is Your Car Safe?," 60 Minutes, vol. 10, no. 40, at 7 (June 11, 1978), cited in W. KEETON, supra note 49, at 491. See also note 119 supra.

Another Ford memo containing some cost-benefit analysis did get to the jury. Its relevance to the case was apparently more clear, but it was nevertheless highly prejudicial to Ford. See note 80 supra.

${ }^{267}$ See C. Wright, Handbook of the Law of Federal Courts 473, 493 (3d ed. 1976). 
careful consideration to motions of this type. The judge should make every effort to cut through the morass of proof, the semantics of the rules of liability, and the rhetoric of counsel to pass judgment at the earliest possible time on whether a fair case really has been made that the manufacturer's conduct was flagrant. If such a fair case has not been made-if, for example, the manufacturer's design choice should instead be placed in the large, gray realm of "close calls" short of moral reprehensibility (as usually will be the case) - the court should relieve the jury of the temptation to base its decision on passion and prejudice, or it should correct the error if the jury in its verdict succumbed to such emotions. In recent years a number of trial courts thus have directed verdicts $^{288}$ and rendered judgments notwithstanding the verdict ${ }^{289}$ on punitive damages claims in products liability cases.

Appellate courts also should subject such awards in products cases to closer scrutiny and reverse them when not supported by the record. ${ }^{270}$ Scrupulous appellate review is especially important

${ }^{208}$ See, e.g., Knippen v. Ford Motor Co., 546 F.2d 993, 1003 (D.C. Cir. 1976) (directed verdict on the issue of punitive damages affirmed); Turney v. Ford Motor Co., $94 \mathrm{Il}$. App. 3d 678, 686, 418 N.E.2d 1079, 1085 (1981) (affirming trial court's decision to strike punitive damages count at end of plaintiff's case). See also Wagner v. International Harvester Co., 611 F.2d 224, 233 (8th Cir. 1979) (district court's denial of plaintiff's motion to amend complaint to include punitive damages issue was proper, and appeal of issue was deemed "to border on the frivolous"); Wangen v. Ford Motor Co., 97 Wis. 2d 260, 298, 294 N.W.2d 437, 457 (1980) (interlocutory appeal) ("Unless there is evidence from which a jury could find that the wrongdoer's conduct was 'outrageous,' the trial court should not submit the issue of punitive damages to the jury."). But see American Motors Corp. v. Ellis, 403 So. 2d 459, 468 (Fla. Dist. Ct. App. 1981) (holding that trial court's directed verdict for manufacturer on punitive damages was in error). The court's acknowledgment that "there was abundant evidence adduced at trial below that AMC simply made a valid business decision to retain the rear-end fuel tank location," id., casts a serious shadow of doubt over the propriety of its ruling.

160 The trial court's judgment notwithstanding the verdict of the jury's $\$ 10$ million verdict in Maxey is the most striking example of this approach. Maxey v. Freightliner Corp., 450 F. Supp. 955, 964 (N.D. Tex. 1978), aff'd, 623 F.2d 395 (5th Cir.), rehearing en banc granted, 634 F.2d 1008 (5th Cir. 1980). See also Kicklighter v. Nails by Jannee, Inc., 616 F.2d 734, 738 (5th Cir. 1980) ( $\$ 60,000)$; McIntyre v. Everest \& Jennings, Inc., 575 F.2d 155, 160 (8th Cir.) (\$45,000), cert. denied, 439 U.S. 864 (1978); Thomas v. American Cystoscope Makers, Inc., 414 F. Supp. 255, 267 (E.D. Pa. 1976) (\$200,000); Newding v. Kroger Co., 554 S.W.2d 15, 18 (Tex. Civ. App. 1977) (\$60,000, combined). But cf. Dorsey v. Honda Motor Co., 655 F.2d 650, 655 (5th Cir. 1981) (reversing district court's judgment notwithstanding the verdict of jury's $\$ 5$ million punitive damages verdict).

${ }^{270}$ Several appellate courts have done so. See, e.g., Johnson v. Husky Indus., Inc., 536 F.2d 645 (6th Cir. 1976); Forrest City Mach. Works, Inc. v. Aderhold, 273 Ark. 33, 616 S.W.2d 720 (1981); Ellis v. Golconda Corp., 352 So. 2d 1221 (Fla. Dist. Ct. App. 1977); Moore v. Remington Arms Co., 100 Ill. App. 3d 1102, 427 N.E.2d 608 (1981); Harley-Davidson Motor Co. v. Wisniewski, 437 A.2d 700, 704-05 (Md. Ct. Spec. App. 1981); American 
because it is a defendant's last hope for reason and calm reflection before the judgment takes effect. On the appeal of such awards, the trial record must be scrutinized with special care for improper evidence, for argument that might have inflamed the jury, and for the sufficiency of the evidence on the whole.

d. Remittiturs. Grimshaw is the largest remittitur of a punitive damages verdict in the history of punitive damages litigation in this context-from $\$ 125$ million to $\$ 3.5$ million, a reduction of 97.2\% ${ }^{271}$ Other courts, both trial and appellate, also have used remittitur to cure excessive punitive verdicts in products cases. ${ }^{272}$ Remittitur may too easily be used improperly as a compromise, however, when an excessive verdict was produced by passion or prejudice and thus should instead be stricken altogether, sometimes along with the verdict for compensatory damages as well. ${ }^{273}$

e. Standard of proof. A number of commentators have proposed that punitive damages, serving as they do as quasi-criminal penalties, should be established by a higher standard of proof than by the usual preponderance of the evidence standard. ${ }^{274}$ Colorado requires that punitive damages be established by proof beyond a reasonable doubt, ${ }^{275}$ and the "clear and convincing" evidentiary standard has been adopted by statute in Oregon ${ }^{278}$ and Minnesota, ${ }^{277}$ by judicial opinion in Wisconsin, ${ }^{278}$ and by the Model

Laundry Mach. Indus. v. Horan, 45 Md. App. 97, 412 A.2d 407 (1980).

${ }^{271}$ Grimshaw v. Ford Motor Co., No. 19-77-61 (Super. Ct., Orange Cty., Cal., Mar. 30, 1978) (mem. order), aff'd, 119 Cal. App. 3d 757, 174 Cal. Rptr. 348 (1981).

${ }_{272}$ See, e.g., Sturm, Ruger \& Co. v. Day, 594 P.2d 38 (Alaska 1979) (reducing \$2.9 million verdict to $\$ 250,000$ permissible maximum on retrial), on rehearing, 615 P.2d 621 (1980) (approving entry of $\$ 500,000$ punitive award); Stambaugh v. International Harvester Co., No. 76-L-2775 (Cir. Ct., St. Clair Cty., Ill., Oct. 26, 1979) (remitting \$15 million verdict to $\$ 7.5$ million, Mar. 10, 1980). The court of appeal in Grimshaw discussed the standards of review on remittitur for both the trial and appellate courts at 119 Cal. App. 3d at 823-24, 174 Cal. Rptr. at 390-91.

${ }^{273}$ See Maxey v. Freightliner Corp., 450 F. Supp. 955, 966 (N.D. Tex. 1978) ("There is a temptation to avoid a direct confrontation with the sufficiency of evidence of defendant's intent by reducing the award. Such an approach misapprehends the court's and jury's role."), aff'd, 623 F.2d 395 (5th Cir.), rehearing en banc granted, 634 F.2d 1008 (5th Cir. 1980).

274 See Owen, supra note 2, at 226 ("It seems both fair and logical to require that the imposition of quasi-criminal punishment, standing halfway between the civil and the criminal law, be supported by a standard of proof halfway between the civil law's 'preponderance of the evidence' and the criminal law's 'proof beyond a reasonable doubt." "); MUPLA, supra note 195, § 120(A), reprinted in 44 FED. REG. at 62,748-49. See also Comment, supra note 37 , at $417-18$.

${ }^{275}$ Colo. Rev. Stat. § 13-25-127(2) (1973).

278 OR. REv. Stat. § 30.925(1) (1979).

${ }^{277}$ Minn. Stat. AnN. $§ 549.20$ (West Supp. 1981). 
Act. ${ }^{279}$ The "clear and convincing" standard's usefulness in resolving "close call" questions on design liability has recently been noted by the Twerski group ${ }^{280}$ and by Professor Henderson. ${ }^{281}$ The standard helps to check the risks faced by manufacturers making daily good faith engineering decisions, and it reminds the court and jury at every step to blow away the smoke and dust of the litigation battle to see if the stuff of truly flagrant conduct is really there.

\section{ConcLusion}

My conclusion in 1976 was that punitive damages awards should be permitted in appropriate products liability cases.$^{282}$ After the judicial experience of 'the ensuing years, I remain convinced of the need to retain this tool of legal control over corporate abuses-a conclusion reinforced by the current Administration's move to restrict the regulation of product safety by the Consumer Product Safety Commission. ${ }^{283}$

Yet the experience of the past several years has raised questions whether the punitive damages doctrine is being abused in products cases, whether some manufacturers are being punished who should not be, and whether penalties, though appropriately assessed, are sometimes unfairly large. One can do little more than speculate about the appropriateness of any particular award in most of the cases. In Grimshaw, for example, although the appellate opinion as written may appear to make a fair case for some award of punitive damages, one is left with nagging doubts concerning some of its key conclusions, such as the feasibility of at least some of the alternative design "fixes" Ford considered and

278 Wangen v. Ford Motor Co., 97 Wis. 2d 260, 299-300, 294 N.W.2d 437, 457-58 (1980). Although not formally adopting the standard, two other courts have noted the importance in such cases of requiring strict proof. See Roginsky v. Richardson-Merrell Inc., 378 F.2d 832, 851-52 (2d Cir. 1967); Maxey v. Freightliner Corp., 450 F. Supp. 955, 963 (N.D. Tex. 1978) ("Demanding strict proof will reduce the hazard of deterrence slipping into destruction to those cases of conduct so egregious as to have little equitable appeal."), aff'd, 623 F.2d 395 (5th Cir.), rehearing en banc granted, 634 F.2d 1008 (5th Cir. 1980).

270 MUPLA, supra note 195, § 120 (A), reprinted in 44 FED. REG. at 62,748.

${ }^{280}$ Twerski, Shifting Perspectives, supra note 50, at 375.

${ }^{281}$ Henderson, Process Defense, supra note 50.

${ }^{282}$ See Owen, supra note 7, at 1371.

${ }^{283}$ The 1982 Budget for the Commission was reduced by thirty percent in the first round of Reagan Administration budget cuts and is slated for further cuts in the future. 9 Prod. SAFETy \& Liab. Rep. 740-41 (1981). 
rejected "reprehensibly."284 Even more disconcerting is the absence of any real explanation of why $\$ 3.5$ million-rather than $\$ 500,000$, $\$ 20$ million, or the jury's $\$ 125$ million figure-was an appropriate amount for the award. Most judicial opinions passing on such awards are considerably weaker even than Grimshaw in failing to explain their rationales. ${ }^{285}$

Because much in both resources and principle is at stake in cases of quasi-criminal punishment against manufacturers, they and the public generally are entitled to much fuller explanation by the courts of why punitive awards should stand or fall. Once the courts and commentators fight through the emotion and maze of words that tend to dominate such cases, we may expect to see a healthy clarification of legal principles begin to emerge. And even if we probably can never find a set of rules that are precise and clear, detailed explanations of judicial results in such cases will give better insight into the true nature of a manufacturer's responsibilities to the public. 